\title{
Global observations of tropospheric BrO columns using GOME-2 satellite data
}

\author{
N. Theys ${ }^{1}$, M. Van Roozendael ${ }^{1}$, F. Hendrick ${ }^{1}$, X. Yang ${ }^{2,3}$, I. De Smedt ${ }^{1}$, A. Richter ${ }^{4}$, M. Begoin ${ }^{4}$, Q. Errera $^{1}$, \\ P. V. Johnston ${ }^{5}$, K. Kreher ${ }^{5}$, and M. De Mazière ${ }^{1}$ \\ ${ }^{1}$ Belgian Institute for Space Aeronomy (IASB-BIRA), Brussels, Belgium \\ ${ }^{2}$ National Centre for Atmospheric Science (NCAS), Cambridge, CB2 1EW, UK \\ ${ }^{3}$ Centre for Atmospheric Science, Department of Chemistry, University of Cambridge, Cambridge CB2 1EW, UK \\ ${ }^{4}$ Institute of Environmental Physics, University of Bremen, Bremen, Germany \\ ${ }^{5}$ National Institute of Water and Atmospheric Research (NIWA), Omakau, Central Otago, New Zealand
}

Received: 8 October 2010 - Published in Atmos. Chem. Phys. Discuss.: 22 November 2010

Revised: 17 February 2011 - Accepted: 20 February 2011 - Published: 25 February 2011

\begin{abstract}
Measurements from the GOME-2 satellite instrument have been analyzed for tropospheric $\mathrm{BrO}$ using a residual technique that combines measured $\mathrm{BrO}$ columns and estimates of the stratospheric $\mathrm{BrO}$ content from a climatological approach driven by $\mathrm{O}_{3}$ and $\mathrm{NO}_{2}$ observations. Comparisons between the GOME-2 results and $\mathrm{BrO}$ vertical columns derived from correlative ground-based and SCIAMACHY nadir observations, present a good level of consistency. We show that the adopted technique enables separation of stratospheric and tropospheric fractions of the measured total $\mathrm{BrO}$ columns and allows quantitative study of the $\mathrm{BrO}$ plumes in polar regions. While some satellite observed plumes of enhanced $\mathrm{BrO}$ can be explained by stratospheric descending air, we show that most $\mathrm{BrO}$ hotspots are of tropospheric origin, although they are often associated to regions with low tropopause heights as well. Elaborating on simulations using the $p$-TOMCAT tropospheric chemical transport model, this result is found to be consistent with the mechanism of bromine release through sea salt aerosols production during blowing snow events. No definitive conclusion can be drawn however on the importance of blowing snow sources in comparison to other bromine release mechanisms. Outside polar regions, evidence is provided for a global tropospheric $\mathrm{BrO}$ background with column of $1-3 \times 10^{13}$ molec cm $^{-2}$, consistent with previous estimates.
\end{abstract}

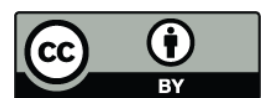

Correspondence to: N. Theys (theys@aeronomie.be)

\section{Introduction}

Inorganic bromine $\left(\mathrm{Br}_{\mathrm{y}}=\mathrm{Br}+\mathrm{BrO}+\mathrm{BrONO}_{2}+\mathrm{HOBr}+\mathrm{HBr}\right.$ $+\mathrm{BrCl})$ is known to play an important role in the chemistry of the stratosphere. Bromine monoxide $(\mathrm{BrO})$ is responsible for ozone depletion through catalytic reactions with $\mathrm{NO}_{2}$, $\mathrm{ClO}, \mathrm{HO}_{2}$ and $\mathrm{O}$ (Lary, 1996). In spite of the small quantities of $\mathrm{Br}_{\mathrm{y}}$ in the stratosphere, it contributes to mid-latitude ozone loss by about $25 \%$ and for polar ozone depletion, mostly through the $\mathrm{BrO} / \mathrm{ClO}$ cycle (McElroy et al., 1986), up to $50 \%$. The main sources of $\mathrm{Br}_{\mathrm{y}}$ in the stratosphere are long-lived organic bromine compounds $\left(\mathrm{CH}_{3} \mathrm{Br}, \mathrm{CBrClF}_{2}\right.$, $\mathrm{CBrF}_{3}, \mathrm{CBrF}_{2} \mathrm{CBrF}_{2}$ ), mostly of anthropogenic origin, which contribute to the stratospheric $\mathrm{Br}_{\mathrm{y}}$ loading by about 16-17 parts per trillion volume (pptv) (Montzka et al., 2003). However, several measurements of stratospheric $\mathrm{BrO}$ using remote-sensing UV-visible techniques have inferred a total $\mathrm{Br}_{\mathrm{y}}$ loading of $18-25$ pptv, suggesting that an additional contribution must be considered, possibly due to the bromine release from short-lived biogenic organic compounds (e.g., $\mathrm{CHBr}_{3}, \mathrm{CH}_{2} \mathrm{Br}_{2}$ ) or even through direct injection of tropospheric $\mathrm{Br}_{\mathrm{y}}$ into the lower stratosphere (WMO, 2007, and references therein; Salawitch et al., 2010).

After the role of bromine in the destruction of stratospheric ozone was highlighted, it became soon clear that inorganic bromine compounds could also have a significant effect in the troposphere (for an overview see, e.g., von Glasow and Crutzen, 2007). In the boundary layer, it was found that large amounts of inorganic bromine are seasonally released in polar region in both hemispheres during spring (e.g., Hausmann and Platt, 1994; Kreher et al., 1997; Wagner and Platt, 1998; Richter et al., 1998; Chance, 1998; Sirois and Barrie, 1999; Hönninger and Platt, 2002; Frieß et al., 2004) due

Published by Copernicus Publications on behalf of the European Geosciences Union. 
to a phenomenon known as polar bromine explosion that involves the release of bromine from sea salt to the gas phase through a sequence of autocatalytic photochemical and heterogeneous reactions (a review is provided in Simpson et al., 2007). However, the mechanism for the bromine release during bromine explosions is not completely understood. The surfaces needed for reactions can potentially come from frost flowers (Kaleschke et al., 2004), fresh sea ice (Frieß et al., 2004), sea salt aerosols (Vogt et al., 1996), sea salt deposits (McConnell et al., 1992) or sea salt aerosols produced during blowing snow events (Yang et al., 2008 and 2010; Jones et al., 2009 and 2010). In any case, the occurrence of such bromine emissions leads to efficient ozone depletion in the polar troposphere (e.g., Wennberg, 1999), as well as interactions with mercury chemistry (Schroeder et al., 1998).

Although more localized, inorganic bromine emissions have also been identified over salt lakes (Hebestreit et al., 1999), in the marine boundary layer (Leser et al., 2003; SaizLopez et al., 2004; Read et al., 2008) and in volcanic plumes (Bobrowski et al., 2003; Oppenheimer et al., 2006; Theys et al., 2009a). Observations from space (e.g., Richter et al., 2002; Van Roozendael et al., 2002), ground-based (Hendrick et al., 2007; Theys et al., 2007) and balloon-borne (Harder et al., 1998; Fitzenberger et al., 2000) instruments have shown that inorganic bromine may be produced and sustained in the free troposphere at the global scale. Elaborating on these observations, modelling results (von Glasow et al., 2004; Lary, 2005; Yang et al., 2005, 2010) have shown that freetropospheric bromine might have a significant impact on the tropospheric ozone budget (and on tropospheric chemistry in general), leading to a reduction in the $\mathrm{O}_{3}$ mixing ratio of up to $40 \%$ locally.

Satellite UV-visible nadir instruments, such as GOME/ERS-2, SCIAMACHY/ENVISAT, GOME2/MetOp-A and OMI/Aura, offer the unique capability to study and monitor $\mathrm{BrO}$ at the global scale (Chance, 1998; Richter et al., 1998, 2002; Van Roozendael et al., 2002; Wagner and Platt, 1998). However, a quantitative and refined interpretation of the satellite $\mathrm{BrO}$ observations requires to resolve the measured total $\mathrm{BrO}$ columns into their stratospheric and tropospheric contributions. In past studies (e.g., Wagner and Platt, 1998; Richter et al., 1998; Hollwedel, 2005), this troposphere-stratosphere separation has been treated only on limited case studies. Generally, the tropospheric $\mathrm{BrO}$ column was derived by subtracting from the measured total column, a stratospheric column estimated from the satellite nadir measurements at the same latitude over a certain geographical sector or at high solar zenith angle (corresponding to high latitude). This implies several assumptions, in particular: (1) a negligible impact of the tropospheric $\mathrm{BrO}$ content on the stratospheric correction, and (2) a weak longitudinal or latitudinal dependence of the stratospheric BrO column. However, these hypotheses are questionable because of the possible overall presence of $\mathrm{BrO}$ in the troposphere and the longitudinal and latitudinal inhomogeneity of stratospheric $\mathrm{BrO}$. The latter point is crucial as it has recently been argued that the stratospheric $\mathrm{BrO}$ column variability could be larger than previously thought, being exacerbated by the supply of significant amounts of $\mathrm{Br}_{\mathrm{y}}$ in the lower stratosphere from short-lived bromocarbons (Salawitch et al., 2010). One possibility to estimate stratospheric $\mathrm{BrO}$ columns at the global scale is to use the $\mathrm{BrO}$ profiles measured by the SCIAMACHY instrument in its limb mode (see e.g. Sinnhuber et al., 2005). Although these profiles are of excellent quality (Hendrick et al., 2009), their use to retrieve tropospheric BrO columns is limited to SCIAMACHY data. Moreover, the retrieval of stratospheric BrO profiles from SCIAMACHY limb observations is most of the time only possible in the altitude range from about $15 \mathrm{~km}$ to $30 \mathrm{~km}$.

In a previous paper (Theys et al., 2009b), we have developed and validated a new stratospheric $\mathrm{BrO}$ climatology that accounts for the important dynamical and photochemical variations of stratospheric BrO. The main motivation was to use it as stratospheric correction in the retrieval of tropospheric $\mathrm{BrO}$ columns from satellite nadir observations. We now apply it to GOME-2 measurements obtained in 2007 and 2008. We have developed an advanced algorithm to retrieve tropospheric $\mathrm{BrO}$ columns that treats the changes in measurement vertical sensitivity in both troposphere and stratosphere due to clouds, surface reflectivity and viewing geometry. Our method enables to separate the large-scale stratospheric and tropospheric $\mathrm{BrO}$ structures in the total $\mathrm{BrO}$ column field measured from space. It allows to better study the polar tropospheric $\mathrm{BrO}$ hotspots and also to further investigate the existence of a free-tropospheric $\mathrm{BrO}$ background at the global scale.

\section{Instrument}

The second Global Ozone Monitoring Experiment (GOME2) is a UV/visible spectrometer covering the $240-790 \mathrm{~nm}$ wavelength interval with a spectral resolution of $0.2-0.5 \mathrm{~nm}$ (Munro et al., 2006). GOME-2 measures the solar radiation backscattered by the atmosphere and reflected from the surface of the Earth in a nadir viewing geometry. A solar spectrum is also measured via a diffuser plate once per day. The ground pixel size is $80 \times 40 \mathrm{~km}^{2}$ and the full width of a normal GOME-2 scanning swath is $1920 \mathrm{~km}$. Global coverage is achieved within 1.5-3 days at the equator and within one day poleward of $\pm 45^{\circ}$ latitude. The GOME-2 instrument was launched on board the Meteorological Operational satelliteA (MetOp-A) in October 2006. The MetOp-A satellite is in a sun-synchronous polar orbit with an equator crossing time of 09:30 LT on the descending node.

The main objective of GOME-2 is the global monitoring of the total ozone field. However, the good spectral resolution and coverage of the instrument also allows for the retrieval of a number of other absorbing trace gases such as $\mathrm{NO}_{2}, \mathrm{SO}_{2}$, 
$\mathrm{H}_{2} \mathrm{CO}, \mathrm{CHOCHO}, \mathrm{OClO}, \mathrm{H}_{2} \mathrm{O}$ and $\mathrm{BrO}$, as well as cloud and aerosol parameters.

\section{Data analysis}

In this work, the tropospheric $\mathrm{BrO}$ vertical column densities $\left(\mathrm{VCD}_{\text {tropo }}\right)$ are retrieved using a residual technique (see e.g., Boersma et al., 2004) according to the following equation:

$\mathrm{VCD}_{\text {tropo }}=\frac{\mathrm{SCD}-\mathrm{VCD}_{\text {strato }} \cdot \mathrm{AMF}_{\text {strato }}}{\mathrm{AMF}_{\text {tropo }}}$

The approach consists of three main steps:

1. A slant column density (SCD) is determined from calibrated earth-shine and irradiance spectra using a DOAS fit, as further explained in Sect. 3.1. This slant column is a "total" SCD in the sense that it includes contributions from absorption by $\mathrm{BrO}$ in both the stratosphere and troposphere.

2. The stratospheric vertical column $\left(\mathrm{VCD}_{\text {strato }}\right)$ is estimated using simulated stratospheric $\mathrm{BrO}$ profiles. Details are given in Sect. 3.2.

3. The residual tropospheric vertical column is obtained by applying stratospheric and tropospheric air mass factors $\left(\mathrm{AMF}_{\text {strato }}\right.$ and $\left.\mathrm{AMF}_{\text {tropo }}\right)$ to account for changes in measurement sensitivity in both stratospheric and tropospheric layers. This aspect is presented in Sect. 3.3.

An error analysis of the tropospheric $\mathrm{BrO}$ vertical columns is then given in Sect. 3.4.

\subsection{DOAS slant column retrieval}

The measured spectra are analysed with the Differential Optical Absorption Spectroscopy (DOAS) technique (Platt and Stutz, 2008). Atmospheric absorbers (in particular BrO) are separated using the characteristic differential structures of their absorption cross-sections determined from laboratory measurements. The retrieved quantity can be regarded as the integrated $\mathrm{BrO}$ concentration along the mean optical light path (it is often referred to as the "slant column density"). Here, the spectral evaluation consists of a least-squares fit procedure where cross-sections of $\mathrm{BrO}(223 \mathrm{~K})$ (Fleischman et al., 2004), ozone (228 K and $243 \mathrm{~K}$ ) (Brion et al., 1993), $\mathrm{NO}_{2}(243 \mathrm{~K})$ (Burrows et al., 1998), $\mathrm{H}_{2} \mathrm{CO}$ (297 K) (Meller et al., 2000) and OClO (293 K) (Bogumil et al., 2003) are adjusted to the log-ratio of a measured and a reference spectrum (the latest solar spectrum measured by the instrument). The absorption cross-sections are convolved using the GOME-2 instrumental slit function (Siddans et al., 2006) and they are corrected for the solar $\mathrm{I}_{0}$ effect (Aliwell et al., 2002). The residual broadband features due to Rayleigh and Mie scattering are removed using a fifth order closure polynomial. A linear offset correction is also applied. To correct for the
Ring effect (Grainger and Ring, 1962), two pseudo absorption cross-sections generated after Vountas et al. (1998) using the SCIATRAN radiative transfer model (Rozanov et al., 2001) are included in the fit. Furthermore, two spectra are included in the fit, to account for the response of the instrument to the polarization of the incoming light (EUMETSAT, GOME-2 FM-203 Calibration Key data, Eta and Zeta).

An important difference in the BrO DOAS settings presented here with respect to our previous study (Theys et al., 2009a) relies in the choice of the fitting window which has been extended towards shorter wavelengths $(332-359 \mathrm{~nm})$ in order to cover five $\mathrm{BrO}$ absorption bands. While the $\mathrm{BrO}$ values retrieved using both fitting windows are consistent above regions of enhanced tropospheric $\mathrm{BrO}$ precursors emissions, the use of this extended wavelength interval leads to an overall reduction of the noise of the slant columns and allows minimising the impact of several well-known artefacts: a spurious slant column viewing angle dependence, the presence in the measurement maps of cloud structures due to imperfect correction of the Ring effect and a strong interference with formaldehyde absorption over regions heavily polluted or affected by biomass burning or biogenic emission. This is illustrated in Fig. 1. In order to better cope with the enhanced ozone absorption at wavelengths shorter than $336 \mathrm{~nm}$, an AMF-modified DOAS approach (Richter, 1997) has been adopted. This considers the product of the wavelength dependent ozone AMFs and the ozone absorption cross-sections in the DOAS analysis rather than the ozone cross-sections alone. The wavelength ozone AMFs used in the present analysis have been calculated for different representative solar zenith angles (SZA) and for a mid-latitudinal ozone profile corresponding to a total column of 450 Dobson units. Note that for SZA lower than $90^{\circ}$ the results are only weakly dependent on the ozone profile and column used in the retrieval.

An example of a BrO fit to GOME-2 data is shown in Fig. 2 for a tropospheric $\mathrm{BrO}$ event. It can be seen that the inclusion of five $\mathrm{BrO}$ absorption bands in the fit yields an unambiguous detection of $\mathrm{BrO}$.

\subsection{Stratospheric BrO correction}

The stratospheric $\mathrm{BrO}$ profiles are estimated using the dynamical climatology of $\mathrm{BrO}$ profiles extensively described in Theys et al. (2009b). The climatology is based on the output of the 3-D chemical transport model BASCOE (Errera et al., 2008; Viscardy et al., 2010) which has been optimized for bromine photochemistry and budget. The total stratospheric inorganic bromine loading is of $23 \mathrm{pptv}$ - including a contribution of 6 pptv by brominated very short-lived substances. Modelled BrO profiles have been validated through comparisons using a large dataset of ground-based, balloon-borne, and satellite limb stratospheric $\mathrm{BrO}$ observations (Theys et al., 2009b). The climatology is based on a parameterization 


\section{GOME-2 BrO VC}

\section{June 2008}

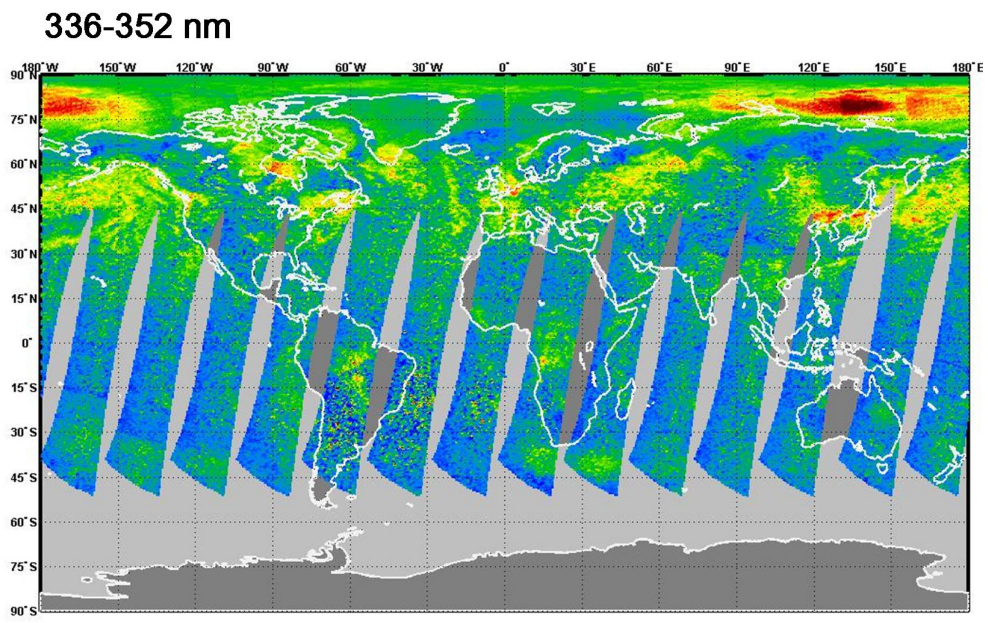

\section{$332-359 \mathrm{~nm}$}

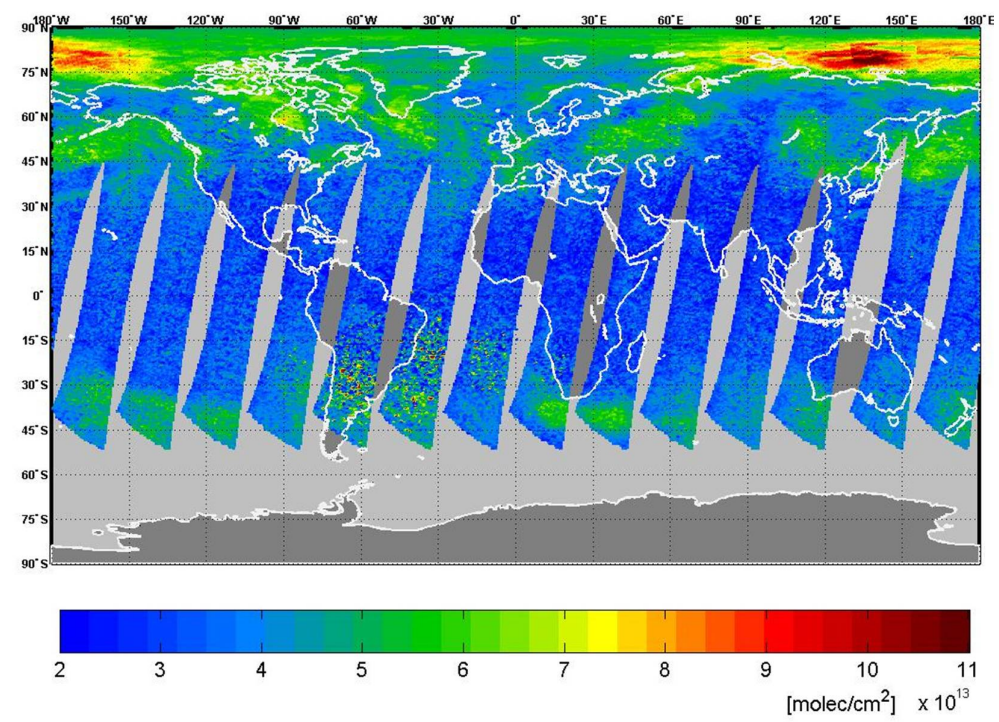

Fig. 1. Comparison of GOME-2 BrO vertical columns for 1 June 2008 using (upper map) the 336-352 nm fitting window from Theys et al. (2009a) and (lower map) the 332-359 nm interval introduced in this study. Simple geometrical air mass factors have been used to convert $\mathrm{BrO}$ slant columns into vertical columns. Note the reduced artefacts due to formaldehyde interference (e.g., in East China or Central Africa), the elimination of the viewing angle dependence and the reduced cloud-related structures.

using dynamical and chemical indicators. The impact of the atmospheric dynamics on the stratospheric $\mathrm{BrO}$ distribution is treated by means of $\mathrm{Br}_{\mathrm{y}} /$ ozone correlations, while photochemical effects are taken into account using stratospheric $\mathrm{NO}_{2}$ columns as an indicator of the $\mathrm{BrO} / \mathrm{Br}_{\mathrm{y}}$ ratio (see e.g., Lary, 1996). In practice, for each sounded pixel, a stratospheric $\mathrm{BrO}$ profile is calculated from the parameterization using the $\mathrm{O}_{3}$ and $\mathrm{NO}_{2}$ (stratospheric) vertical columns retrieved by the Deutsches Zentrum für Luft- und Raumfahrt (DLR, level-2 operational product, GDP 4.3) from the same
GOME-2 measurement. This approach is convenient since it requires only limited computational resources. Moreover, as the climatology uses measured quantities to evaluate stratospheric $\mathrm{BrO}$, it guarantees that the sounded air masses and geophysical conditions are optimally represented.

The stratospheric $\mathrm{BrO}$ vertical columns are derived by integrating simulated stratospheric $\mathrm{BrO}$ profiles between the tropopause and the top-of-atmosphere. The tropopause is calculated using the potential vorticity (PV) determined on isentropic levels from meteorological data of the European 

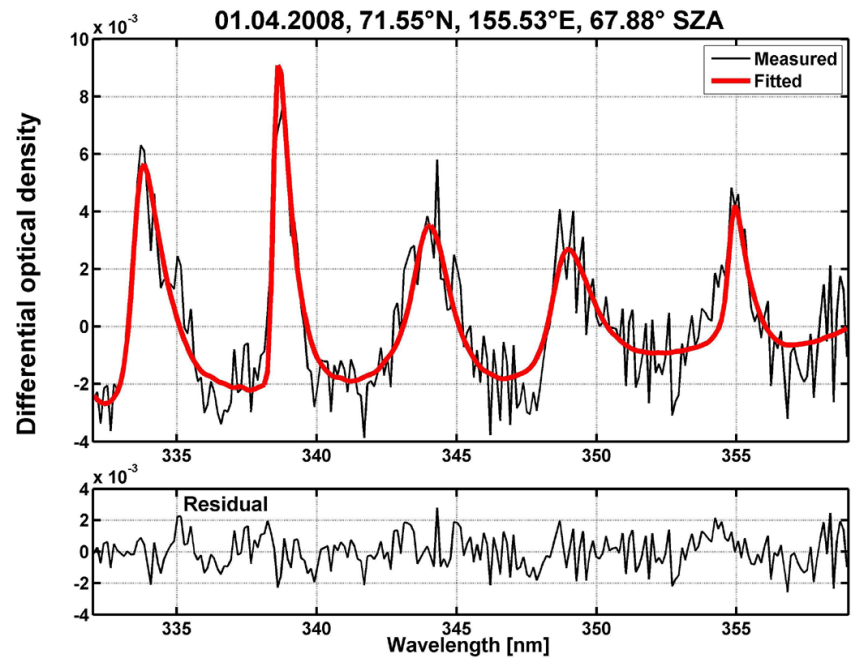

Fig. 2. Example of a fit to the measured $\mathrm{BrO}$ differential absorption in the 332-359 $\mathrm{nm}$ wavelength interval during a tropospheric $\mathrm{BrO}$ event. The slant column is $6.14 \times 10^{14}$ molec cm $^{-2}$.

Centre for Medium-Range Weather Forecasts (ECMWF) sampled on a $1^{\circ} \times 1^{\circ}$ latitude-longitude grid (ERA-Interim analysis). The tropopause height is defined by the $3.5 \mathrm{PVU}$ contour $\left(1 \mathrm{PVU}=10^{-6} \mathrm{~m}^{2} \mathrm{~K} \mathrm{~s}^{-1} \mathrm{~kg}^{-1}\right)$, joined to the $380 \mathrm{~K}$ isentropic surface in the tropics where the 3.5 PVU contour rises above this level. This so-called dynamical tropopause agrees reasonably well with the thermal tropopause, defined in terms of the temperature lapse rate by the World Meteorological Organization (WMO), despite a general tendency to give a tropopause lower by $1 \mathrm{~km}$ on average (Schoeberl, 2004), with a small effect on the stratospheric BrO column calculation (maximum 3\% differences). We have decided to use the dynamical tropopause height rather than the thermal tropopause essentially because the latter is generally undefined for typical Antarctic ozone hole conditions (where the condition $\mathrm{dT} / \mathrm{dz}>-2 \mathrm{~K} / \mathrm{km}$ is often encountered only in the stratosphere above $15 \mathrm{~km}$ altitude). In a last step, a fine

adjustment of the climatology is performed to ensure consistency with GOME-2 measurements. The approach is similar in concept to the correction used for the retrieval of tropospheric $\mathrm{NO}_{2}$ columns by Richter et al. (2005). Here the correction is based on the fact that the variations in stratospheric $\mathrm{Br}_{\mathrm{y}}$ are controlled by atmospheric dynamics in a way that matches closely the $\mathrm{O}_{3}$ fluctuations, as clearly established by Theys et al. (2009b) and further demonstrated by Salawitch et al. (2010) using measured $\mathrm{O}_{3}$ and $\mathrm{BrO}$ vertical columns. We assume that in conditions described below the slope of a $\mathrm{BrO}$ versus $\mathrm{O}_{3}$ regression plot is fully controlled by stratospheric $\mathrm{BrO}$. The correction then consists in adjusting the slope of the modelled $\mathrm{BrO} / \mathrm{O}_{3} \mathrm{VCD}$ correlation plot to the measured total $\mathrm{BrO} / \mathrm{O}_{3} \mathrm{VCD}$. In this procedure, the modelled and measured total $\mathrm{BrO}$ vertical columns are col-

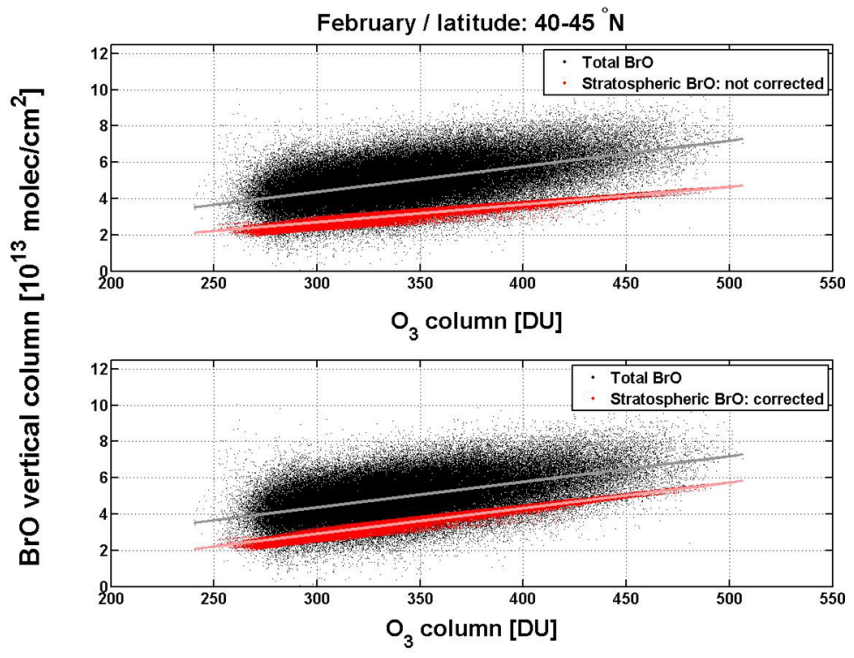

Fig. 3. Illustration of the adjustment procedure used to bring the stratospheric $\mathrm{BrO}$ climatology in close agreement with GOME-2 measurements for the Northern Hemisphere (February $\left(40-45^{\circ} \mathrm{N}\right)$ ). After adjustment, the slope of the regression line between the stratospheric $\mathrm{BrO}$ VCDs and the $\mathrm{O}_{3}$ VCDs (light red line) is equal to the slope of the regression line through the scatterplot between the measured total $\mathrm{BrO}$ VCDs and the $\mathrm{O}_{3}$ VCDs (grey line). Note that the total $\mathrm{BrO}$ columns are calculated using stratospheric air mass factors.

lected for two mid-latitudinal bands $\left(40-45^{\circ} \mathrm{N}\right.$ and $40-45^{\circ} \mathrm{S}$, to construct separate correction for the Northern and Southern Hemispheres). In order to best constrain the slope of the scatter plots, we have considered the data for the months of February and August (for the corrections of the Northern and Southern Hemispheres, respectively) as on the one hand, a large variability in $\mathrm{O}_{3}$ columns is observed at mid-latitudes for these months (due to strong dynamical changes of the stratosphere), and on the other hand, possible contamination of the measurements by elevated boundary layer $\mathrm{BrO}$ (e.g., transported from the polar region) is negligible. Note that the correction described here uses a slope adjustment but leaves unchanged any possible offset between modelled and measured total $\mathrm{BrO} \mathrm{VCD}$. Hence it preserves the information on the $\mathrm{BrO}$ background (not correlated with ozone) presumably present in the free-troposphere. This is achieved by keeping fixed the point at $250 \mathrm{DU}$ of the modelled (adjusted) regression line, which reflects the fact that the discrepancy between the modelled and the measured $\mathrm{BrO}$ columns is likely to be larger for high $\mathrm{O}_{3}$ columns. An illustration of the Northern Hemisphere correction is given in Fig. 3.

\subsection{Air mass factors calculation}

The air mass factor is defined by the ratio of the slant column to the vertical column (AMF $=\mathrm{SCD} / \mathrm{VCD})$. In this study the air mass factors are calculated under the assumption of optically thin atmospheric absorbers. For these conditions, 
the scattering weight formulation introduced by Palmer et al. (2001) can be used:

$\mathrm{AMF}=\int W F(z) N(z) d z$

In this expression, $N(z)$ is the concentration profile of the atmospheric species of interest normalized by the corresponding vertical column and $W F(z)$ is the so-called weighting function (no unit) that contains the dependences on all the parameters influencing the AMF, except the vertical profile of the species $N(z)$. The stratospheric and tropospheric air mass factors are estimated by integrating Eq. (2) over the altitude ranges of interest (from the surface to the tropopause, and from the tropopause to the topof-atmosphere, respectively) using stratospheric (Sect. 3.2) and tropospheric (Sect. 3.3.3) BrO profiles, respectively. The weighting function depends on the observation geometry and on the scattering properties of the atmosphere and the surface. In this work, WFs have been evaluated from radiative transfer calculations performed with the pseudospherical multiple scattering UVSpec/DISORT code (Mayer and Killing, 2005). WFs have been modelled for a number of representative viewing geometries (solar zenith angles, viewing zenith angles and relative azimuth angles), surface albedos and ground altitudes, and stored in a look-up-table. Calculations are made at $345.5 \mathrm{~nm}$, i.e. the centre wavelength of the fitting interval used. Sensitivity tests have been carried out in order to estimate the wavelength dependency of the calculated air mass factors within the fitting interval (332$359 \mathrm{~nm}$ ). Results from these sensitivity tests show that using the centre wavelength of the interval $(345.5 \mathrm{~nm})$ leads to errors on the AMFs that are smaller than 5\%, except for low sun conditions (solar zenith angles larger than $85^{\circ}$, not considered in our retrieval).

\subsubsection{Impacts of clouds and surface albedo}

The treatment of partially cloudy pixels (characterized by an effective cloud fraction area $f$ ) is based on the hypothesis of the "independent pixel approximation". It is assumed that the intensity measured by the instrument is the sum of the intensities of a completely clear and a completely cloudy pixel weighted by $(1-f)$ and $f$ respectively. Under such circumstances, the weighting function for a partially cloudy scene is given by (Martin et al., 2002):

$W F(z)=\Phi \cdot W F_{\text {cloud }}(z)+(1-\Phi) \cdot W F_{\text {clear }}(z)$

where $W F_{\text {cloud }}(z)$ is the weighting function for a completely cloudy scene, and $W F_{\text {clear }}(z)$ is the weighting function for a corresponding cloud-free pixel. $\Phi$ is the intensity-weighted cloud fraction:

$\Phi=\frac{f I_{\text {cloud }}}{f I_{\text {cloud }}+(1-f) I_{\text {clear }}}$

$I_{\text {cloud }}$ and $I_{\text {clear }}$ being the backscattered intensities for fully cloudy and clear scenes, respectively. The variables in

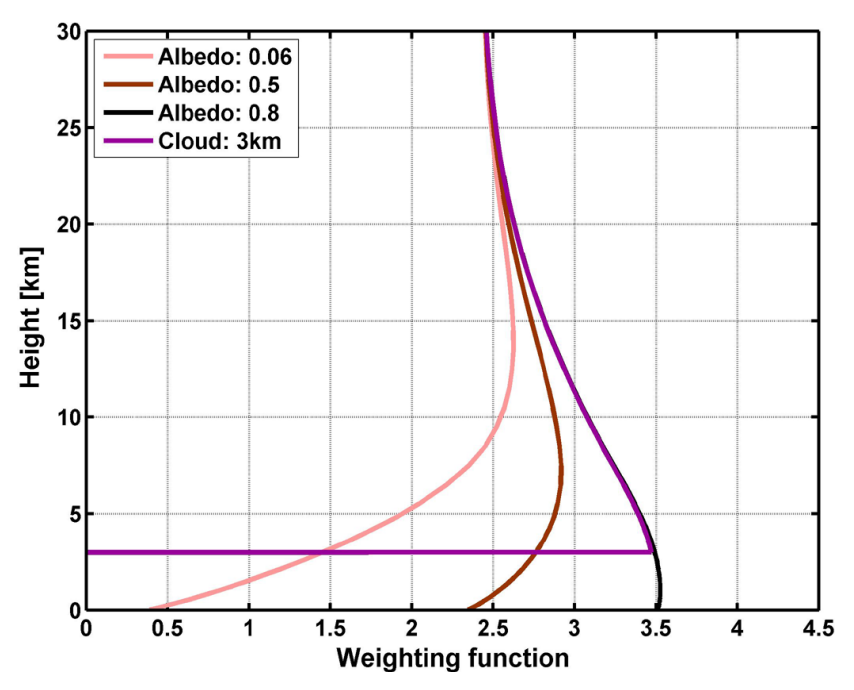

Fig. 4. Satellite weighting functions at $345.5 \mathrm{~nm}$ as function of surface albedo (0.06, 0.5 and 0.8 for a surface at sea level) and for a fully cloudy scene (cloud top height: $3 \mathrm{~km}$, cloud albedo: 0.8 ). Calculations are made for a pure nadir observation geometry (lineof-sight angle: $0^{\circ}$ ) and a solar zenith angle of $45^{\circ}$.

Eq. (3) are estimated using the cloud fraction retrieved by the FRESCO+ algorithm (Wang et al., 2008) and by considering two Lambertian reflectors consistent with the FRESCO+ settings: one reflector representing the cloud at the retrieved cloud top pressure (albedo: 0.8 ) and the other one representing the surface with an albedo taken from the climatology of Koelemeijer et al. (2003) but at a wavelength of $335 \mathrm{~nm}$ (more in line with the wavelengths used to retrieve the $\mathrm{BrO}$ slant columns). To minimize the bias resulting from clouds, the analysis includes only the measurements with a cloud fraction below 0.4 and with a pressure difference between the surface and the top of the cloud less than 400 mbar. Note that no explicit correction is applied for aerosols but the cloud correction scheme accounts for a large part of the aerosol scattering effect (Boersma et al., 2004).

An illustration of the weighting functions $\left(W F_{\text {clear }}(z)\right.$ and $\left.W F_{\text {cloud }}(z)\right)$ is given in Fig. 4 , for a clear-sky case with a surface altitude of $0 \mathrm{~km}$ (assuming a surface albedo of 0.06 , 0.5 and 0.8 ) and for a cloudy case with a cloud top height of $3 \mathrm{~km}$. It shows the typical behaviour of the satellite nadir UV measurement sensitivity to an absorber located at different altitudes for various surface albedo situations and for a totally cloudy scene.

\subsubsection{Treatment of snow/ice-covered surfaces}

Surfaces covered by snow or ice are of particular importance for the retrieval of tropospheric $\mathrm{BrO}$ columns since the large concentrations of $\mathrm{BrO}$ in the polar boundary layer are generally observed over bright surfaces. Unfortunately, FRESCO+ is unable to derive an effective cloud fraction for high albedo scenes, because this fraction is basically determined from the 
contrast of the cloud with respect to the underlying surface. Nevertheless, we exploit the FRESCO + data in the snow/ice dedicated mode by considering the retrieved cloud top pressure and albedo as representative of the sounded surface and by using these Lambertian surface properties to calculate the WFs. Only scenes for which the difference between the surface pressure and the retrieved cloud top pressure is below 120 mbar are considered, so that pixels contaminated by thick elevated clouds are eliminated from the analysis.

A special case has also been designed for the fresh snow scenes: as the snow/ice mode of FRESCO+ is triggered by a monthly-averaged albedo database, pixels covered by fresh snow are not detected in this mode, but are considered as cloudy pixels in the nominal mode of FRESCO+. Hence, to account for these fresh snow scenes, we include in the analysis the pixels with a cloud fraction larger than 0.7 and with a pressure difference between the surface and the top of the "cloud" smaller than 150 mbar.

\subsubsection{Tropospheric BrO profile shape}

Since the vertical distribution of $\mathrm{BrO}$ in the troposphere is largely unknown (Neuman et al., 2010), we have considered two different approaches depending on the surface albedo value:

1. High albedo $(>50 \%)$ : this is the ideal case, with a high sensitivity for $\mathrm{BrO}$ close to the surface and a weak dependence of the tropospheric AMF to the shape of the profile (see Fig. 4, brown and black curves). We have made a provisional choice for a tropospheric $\mathrm{BrO}$ concentration profile constant in the first $\mathrm{km}$ above the Lambertian surface reflector.

2. Low albedo $(<50 \%)$ : as the measurement sensitivity over dark surfaces (such as oceans) is strongly reduced in the boundary layer, we have assumed the tropospheric $\mathrm{BrO}$ profile to have only a contribution in the free-troposphere (where the measurement sensitivity is larger by about a factor of five compared to the boundary layer; see Fig. 4). As a result, the retrieved tropospheric $\mathrm{BrO}$ columns in such situations are only representative of the free-troposphere, and any $\mathrm{BrO}$ amount present in the boundary layer will be largely underestimated. In contrast, the results for high albedo scenes are sensitive to the entire tropospheric vertical column, i.e. free-troposphere and boundary layer. The choice of a free-tropospheric $\mathrm{BrO}$ profile constitutes a limitation of our approach; however it is justified by the fact that the typical tropospheric abundances of $\mathrm{BrO}$ in the extra-polar boundary layer are either below the detection limit of the satellite instrument or correspond to localized emissions with a spatial extent smaller than the typical pixel size. Our baseline for the retrieval has been to assume a Gaussian profile with a maximum at $6 \mathrm{~km}$ high and a full width half maximum of $2 \mathrm{~km}$, consistent with the observed profile of Fitzenberger et al. (2000). The sensitivity of the retrieval to this assumption will be further discussed in Sect. 4.2.

\subsection{Error analysis}

The total retrieval uncertainty on the tropospheric $\mathrm{BrO}$ vertical columns can be derived by error propagation starting from Eq. (1). Considering the different steps of the retrieval algorithm as independent and uncorrelated, the total error on the tropospheric vertical column can be expressed as (Boersma et al., 2004; De Smedt et al., 2008):

$$
\begin{aligned}
\sigma_{\mathrm{VCD}_{\text {tropo }}}^{2}= & \frac{1}{N} \cdot\left(\frac{\sigma_{\mathrm{SCD}_{\text {rand }}}}{\mathrm{AMF}_{\text {tropo }}}\right)^{2}+\left(\frac{\sigma_{\mathrm{SCD}_{\text {syst }}}}{\mathrm{AMF}_{\text {tropo }}}\right)^{2}+\left(\frac{\sigma_{\mathrm{SCD}_{\text {strato }}}}{\mathrm{AMF}_{\text {tropo }}}\right)^{2} \\
& +\left(\frac{\left(\mathrm{SCD}-\mathrm{SCD}_{\text {strato }}\right) \cdot \sigma_{\mathrm{AMF}_{\text {tropo }}}}{\mathrm{AMF}_{\text {tropo }}^{2}}\right)^{2}
\end{aligned}
$$

where $\mathrm{SCD}_{\text {strato }}=V C D_{\text {strato }} \cdot \mathrm{AMF}_{\text {strato }}$ denotes the stratospheric $\mathrm{BrO}$ slant column.

$\sigma_{\mathrm{SCD}_{\text {rand }}}$ and $\sigma_{\mathrm{SCD}_{\text {syst }}}$ are the random and systematic parts of the error on the slant columns. The random error is reduced when the number of measurements increases. Therefore, in case of averaging, $\sigma_{\mathrm{SCD}_{\text {rand }}}$ can be divided by the square root of the number of satellite pixels taken into the mean $(\mathrm{N}) . \sigma_{\mathrm{SCD}_{\text {strato }}}$ and $\sigma_{\mathrm{AMF}_{\text {tropo }}}$ stand for the errors (considered systematic) on the stratospheric slant column and the tropospheric air mass factor, respectively. For each pixel, we have calculated a rough estimate of the random and systematic parts of the error on the tropospheric $\mathrm{BrO}$ vertical column. The random slant column error is evaluated for each satellite orbit by the standard deviation of the measured columns around the mean for latitude bands of $5^{\circ}$ width. Based on calculations using the formalism of Rodgers (2000) (see also Theys et al., 2007), sensitivity tests made on GOME-2 spectra and the experience with $\mathrm{BrO}$ retrieval from GOME and SCIAMACHY (Van Roozendael et al., 2002 and 2004), a typical systematic slant column error of about $20 \%$ including the uncertainty on the $\mathrm{BrO}$ crosssection and its temperature dependence has been estimated. For the error on the stratospheric slant column, we consider an error equal to 20\%, as derived in Theys et al. (2009b). The error on the tropospheric AMF depends on uncertainties on the input parameters (surface albedo, cloud fraction, cloud top height and tropospheric $\mathrm{BrO}$ profile shape) and on the sensitivity of the air mass factor to each of them. An estimate of the tropospheric AMF error due to an individual input parameter error is obtained by applying a perturbation method. The total error on the tropospheric AMF is then calculated from the sum of squares of the contributions to the tropospheric AMF error due to errors on the individual input parameters. The latter input parameter absolute uncertainties are taken as follows (Koelemeijer et al., 2002 and 2003): surface albedo error: 0.02 , cloud fraction error: 0.05 and cloud 
top height error: $1 \mathrm{~km}$. The error on the profile shape is estimated considering a $2 \mathrm{~km}$ uncertainty on the bulk altitude of the $\mathrm{BrO}$ profile.

\section{Verification of the retrievals}

In this section, the reliability of the GOME-2 BrO columns is assessed through comparisons with SCIAMACHY satellite nadir observations (total $\mathrm{BrO}$ columns) and independent ground-based observations (stratospheric and tropospheric BrO columns).

\subsection{Comparison to SCIAMACHY nadir observations}

SCIAMACHY is in operation on the ENVISAT platform since July 2002. The instrument flies on polar sunsynchronous orbits and crosses the equator 30 minutes after GOME-2 (at 10:00 LT). The instrument observes the Earth's atmosphere in limb, nadir and occultation viewing geometries. The measurements are performed in eight channels covering the $240-2380 \mathrm{~nm}$ wavelength range with a spectral resolution of 0.2 to $1.5 \mathrm{~nm}$. A detailed description of SCIAMACHY can be found in Bovensmann et al. (1999). In this study, we use the nadir $\mathrm{BrO}$ total columns derived at the Institute of Environmental Physics (IUP) of the University of Bremen. A description of the retrieval algorithm can be found in Afe et al. (2004). However, the most recent retrieval version differs slightly in the retrieval settings. The spectral analysis is performed in the $336-351 \mathrm{~nm}$ interval (instead of the less stable 336-347 nm interval in Afe et al., 2004) and includes the absorption of $\mathrm{BrO}(243 \mathrm{~K}), \mathrm{O}_{3}$ $(223 \mathrm{~K}$ and $243 \mathrm{~K}), \mathrm{NO}_{2}(223 \mathrm{~K}), \mathrm{O}_{4}$ as well as two Ring pseudo-spectra for correction of the effect of Rotational Raman scattering and a polynomial of order 4 . To account for long-term drifts in the SCIAMACHY data, all slant columns are normalised to the daily value observed over the equatorial Pacific $\left(150^{\circ} \mathrm{E}-270^{\circ} \mathrm{E}\right.$ longitude, $10^{\circ} \mathrm{S}$ to $10^{\circ} \mathrm{N}$ latitude) assuming a constant vertical column of $3.5 \times 10^{13}$ molec $\mathrm{cm}^{-2}$. A similar correction has previously been applied to GOME BrO measurements (Richter et al., 2002) While this improves the overall consistency of the SCIAMACHY BrO data set, it also removes any real seasonal or interanual variability in the data over the equator. For our comparison exercise, we have calculated averaged total $\mathrm{BrO}$ columns from SCIAMACHY and GOME-2 observations $\left(\mathrm{SZA}<80^{\circ}\right.$ ) for six latitudinal bands $\left(60-90^{\circ} \mathrm{S}, 30-60^{\circ} \mathrm{S}, 0-30^{\circ} \mathrm{S}, 0-30^{\circ} \mathrm{N}, 30-\right.$ $60^{\circ} \mathrm{N}, 60-90^{\circ} \mathrm{N}$ ), for each day in 2007 and 2008. For this purpose, we have applied simple geometrical air mass factors (i.e., $\mathrm{AMF}=\sec \left(\theta_{0}\right)+\sec (\theta)$ where $\theta_{0}$ and $\theta$ are the solar and viewing zenith angles, respectively) to the retrieved slant columns of both instruments. Figure 5 shows the comparison results. The agreement between GOME-2 and SCIAMACHY BrO columns is generally good; the seasonality of $\mathrm{BrO}$ being consistently captured at all latitudes by both satellite data. The differences between SCIAMACHY and GOME-2 total columns are most of the time lower than $\pm 0.5 \times 10^{13}$ molec $\mathrm{cm}^{-2}$. Considering the systematic uncertainties on satellite measurements typically of the order of $1 \times 10^{13}$ molec cm $^{-2}$, the observed differences are within the error bars.

\subsection{Comparison to ground-based observations}

Ground-based UV-visible zenith-sky observations of $\mathrm{BrO}$ have been performed at Harestua $\left(60^{\circ} \mathrm{N}, 11^{\circ} \mathrm{E}\right.$; operated by IASB-BIRA) and Lauder $\left(45^{\circ} \mathrm{S}, 170^{\circ} \mathrm{E}\right.$; operated by NIWA). Both stations belong to the Network for the Detection of Atmospheric Composition Change (NDACC) and are remote sites not influenced by local pollution sources. Measured radiance spectra are analysed for differential $\mathrm{BrO}$ slant column densities using the DOAS technique. The profiling algorithm described and extensively used in Hendrick et al. $(2007,2008$ and 2009) is then applied to the ground-based $\mathrm{BrO}$ slant column densities in order to retrieve $\mathrm{BrO}$ vertical profiles. Stratospheric and tropospheric $\mathrm{BrO}$ columns are calculated by integrating the retrieved profiles in the appropriate altitude ranges. As the retrieved ground-based $\mathrm{BrO}$ profiles are representative of the situation at twilight, a photochemical correction is applied in order to match the solar zenith angle corresponding to the satellite overpass time. Figure 6 shows the comparison between the ground-based and the coincident GOME-2 stratospheric (climatology) and tropospheric BrO columns for the period 2007-2008, at Harestua. Daily mean GOME-2 BrO column amounts are calculated based on the full retrieval technique described in Sect. 3 and using all pixels (that are not rejected by the cloud selection criteria) with a solar zenith angle lower than $80^{\circ}$ and falling within a radius of $200 \mathrm{~km}$ around Harestua. In general, climatological $\mathrm{BrO}$ stratospheric vertical columns are found to be in good agreement with the stratospheric columns inferred from the ground-based observations, in terms of mean level and seasonal variation (with a tendency to produce lower values by $0.15 \pm 0.510^{13} \mathrm{molec} \mathrm{cm}^{-2}$ on average). Note that even short-term variations of the stratospheric column are well captured by both datasets, especially in spring. Figure 6 also indicates that both satellite and ground-based observations are consistent with a tropospheric BrO column of $1.5 \times 10^{13}$ molec $\mathrm{cm}^{-2}$. Note that the GOME-2 tropospheric BrO columns are weakly dependent on the bulk altitude of the tropospheric $\mathrm{BrO}$ profile assumed in the retrieval $(6 \mathrm{~km}$ or $8 \mathrm{~km}$, blue and black lines, respectively).

Using the same settings, Fig. 7 shows the comparison between GOME-2 and ground-based stratospheric and tropospheric BrO columns at Lauder, for the period September 2007-October 2008. The agreement between GOME2 and ground-based data is generally good for the stratospheric columns. For Southern hemisphere winter time, the stratospheric climatology has however a tendency to produce 

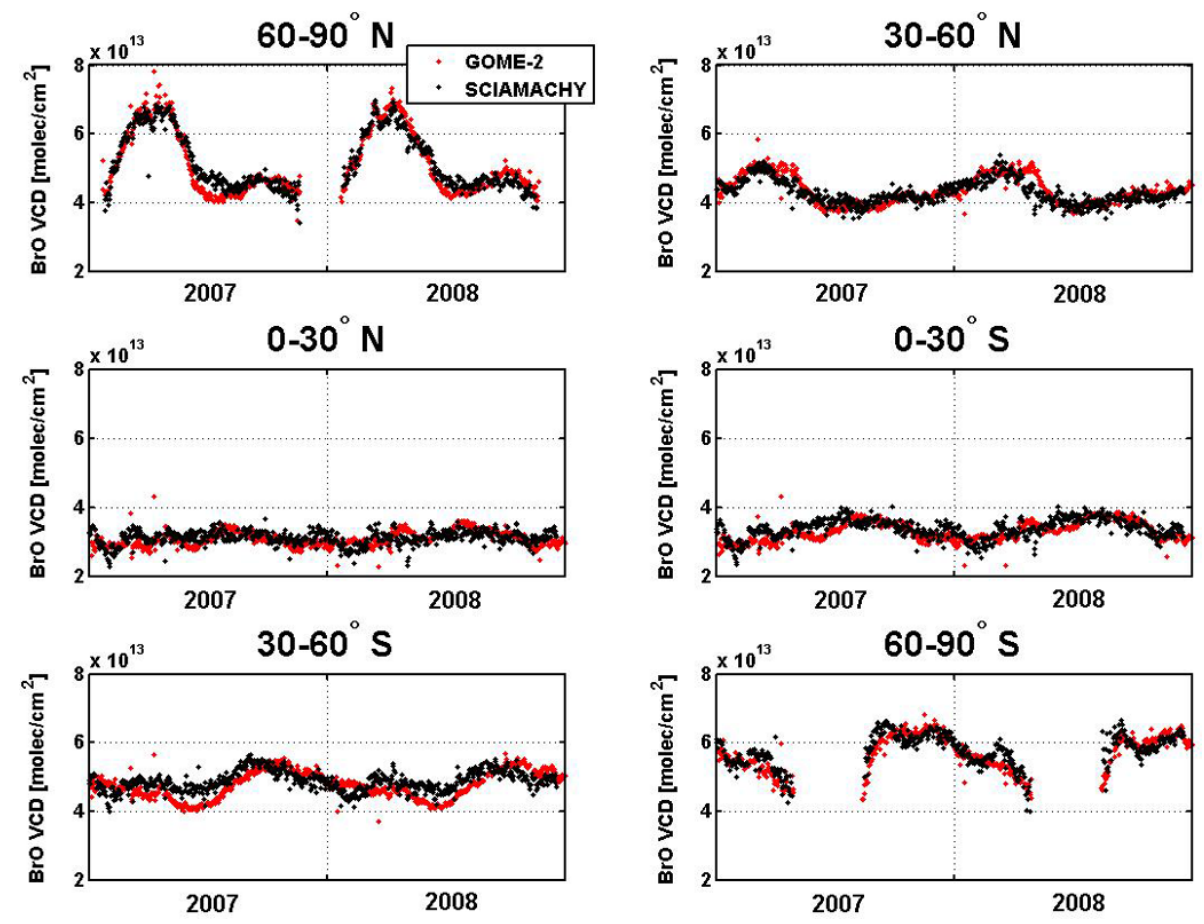

Fig. 5. Time-series of total BrO vertical columns from GOME-2 and SCIAMACHY nadir observations for different latitudinal bands (daily zonal averages). Only data corresponding to solar zenith angles lower than $80^{\circ}$ are shown.
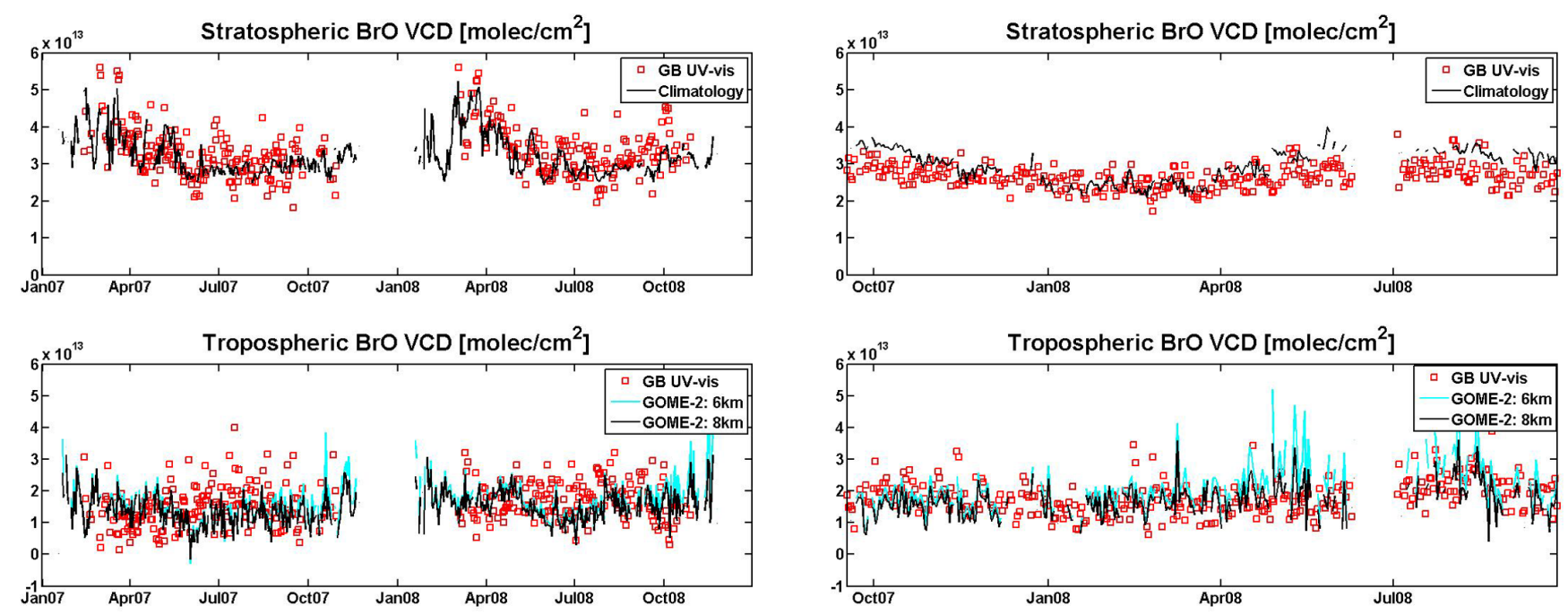

Fig. 6. Comparison between GOME-2 and ground-based stratospheric (upper plot) and tropospheric (lower plot) $\mathrm{BrO}$ vertical columns, at Harestua for the period 2007-2008. Two assumptions are made in the GOME-2 retrieval algorithm for the height $(6 \mathrm{~km}$ : blue line, $8 \mathrm{~km}$ : black line) of the maximum tropospheric $\mathrm{BrO}$ concentration (see text).

slightly higher values than the ground-based data (by $\sim 0.5 \times 10^{13} \mathrm{molec} / \mathrm{cm}^{2}$ ). The agreement between GOME2 and ground-based tropospheric columns is generally also

Fig. 7. Same as Fig. 6, at Lauder for the period September 2007October 2008.

good, except from mid-April to end August 2008 where the GOME-2 tropospheric BrO columns (blue line) are systematically higher than the values retrieved from the ground-based observations (mean bias: $0.7 \times 10^{13} \mathrm{molec} / \mathrm{cm}^{2}$ ). It should be noted that the winter period at Lauder corresponds to conditions of high SZA and low surface albedo (not encountered at Harestua), making the weighting functions critically 


\section{Tropospheric BrO VCD}
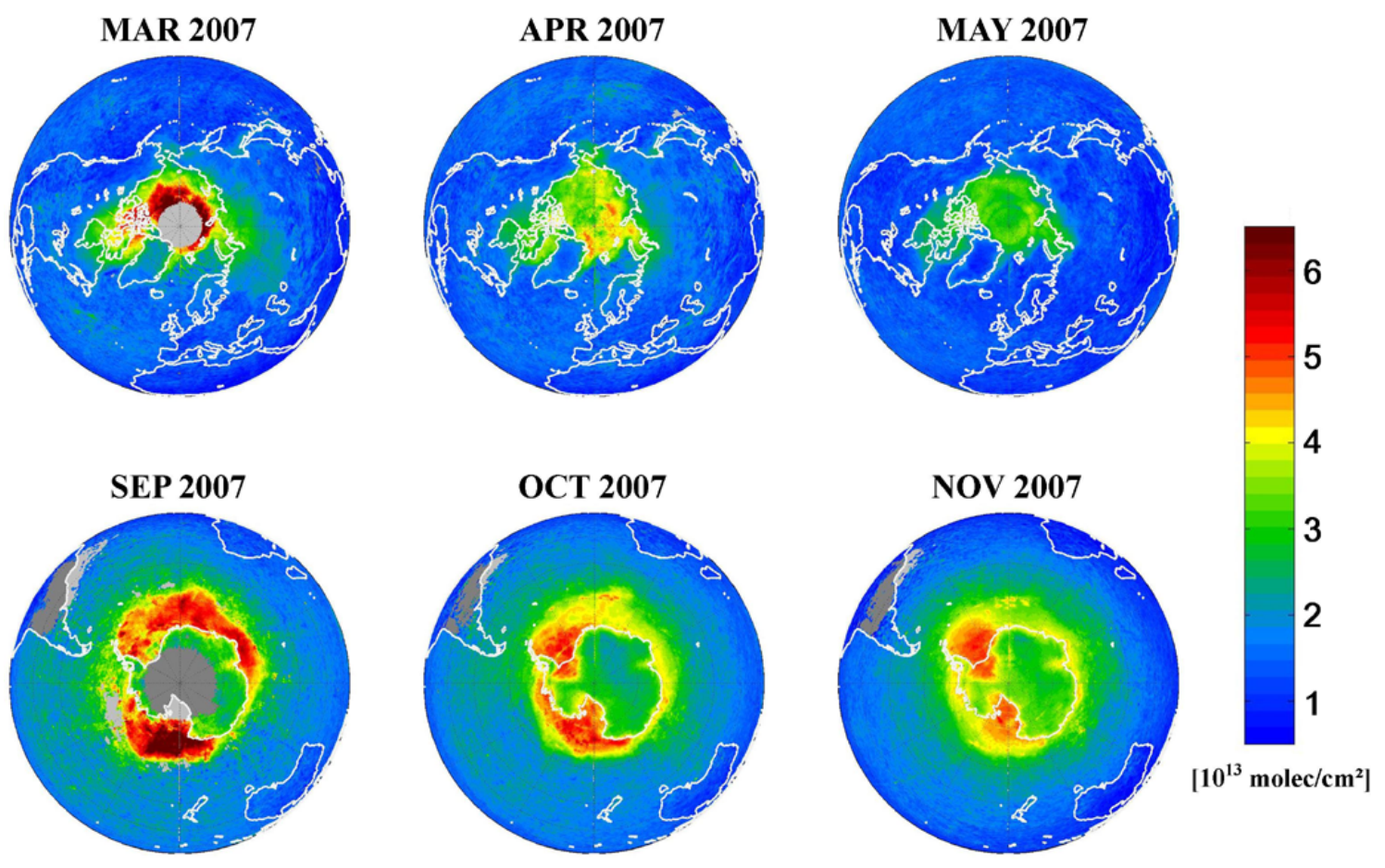

Fig. 8. Monthly averages of GOME-2 tropospheric $\mathrm{BrO}$ vertical columns in polar spring 2007 for the Northern Hemisphere (upper plots) and the Southern Hemisphere (lower plots). Only data corresponding to solar zenith angles lower than $80^{\circ}$ are used.

dependent on the altitude in the troposphere and therefore yielding a rather uncertain stratosphere-troposphere $\mathrm{BrO}$ separation. If one assumes a tropospheric $\mathrm{BrO}$ profile shape peaking at $8 \mathrm{~km}$ (black lines in Fig. 7) rather than $6 \mathrm{~km}$ (as it is routinely used in our standard retrieval), the agreement between satellite and ground-based data significantly improves (with GOME-2 being lower than the ground-based data by $0.13 \pm 0.710^{13}$ molec cm $^{-2}$ on average). Note however that this is not a firm proof for $\mathrm{BrO}$ being higher up. One can say that given the uncertainties on the tropospheric air mass factor at Lauder, ground-based and GOME-2 BrO observations agree reasonably well.

From Figs. 6 and 7, we conclude that both ground-based and satellite observations are consistent with a tropospheric $\mathrm{BrO}$ column of $\sim 1.5 \times 10^{13}$ molec $\mathrm{cm}^{-2}$ for morning conditions ( 09:30 solar local time), although the errors on the tropospheric $\mathrm{BrO}$ columns are rather large: typically around $0.5 \times 10^{13}$ molec cm $\mathrm{cm}^{-2}$ for the ground-based data and about $0.8-1.5 \times 10^{13}$ molec cm$^{-2}$ for the satellite observations.

\section{Results and discussion}

Using the retrieval scheme described in Sect. 3, tropospheric $\mathrm{BrO}$ columns have been computed for GOME-2 measurements taken in 2007 and 2008. As an example, Fig. 8 dis- plays the spatial distribution of the monthly averaged tropospheric $\mathrm{BrO}$ columns from GOME-2 for the polar spring period 2007 in both hemispheres (analogous results are obtained for the year 2008). The areas left in grey correspond to zones with no satellite overpass, solar zenith angles larger than $80^{\circ}$ or regions strongly affected by the South Atlantic Anomaly in the earth geomagnetic field (over South America). In Fig. 8, large BrO columns are observed during polar spring in both hemispheres. These events are related to polar tropospheric $\mathrm{BrO}$ precursors emissions and have already been highlighted in previous studies (Wagner and Platt, 1998; Richter et al., 1998, 2002; Chance, 1998). The regions with enhanced tropospheric $\mathrm{BrO}$ columns exhibit an excellent correlation with the areas of sea ice. The difference in $\mathrm{BrO}$ distribution between both hemispheres mainly reflects the differences in sea-ice distribution.

\subsection{Stratospheric BrO}

We first concentrate on demonstrating the suitability of the stratospheric $\mathrm{BrO}$ climatology used in this work (Sect. 3.2), in particular its ability to reproduce the observed spatial structures of stratospheric BrO, and to correct for them. As an illustration, Fig. 9 presents a comparison between GOME2 total $\mathrm{BrO}$ columns (estimated using stratospheric AMFs, no cloud filtering) and the corresponding stratospheric $\mathrm{BrO}$ 


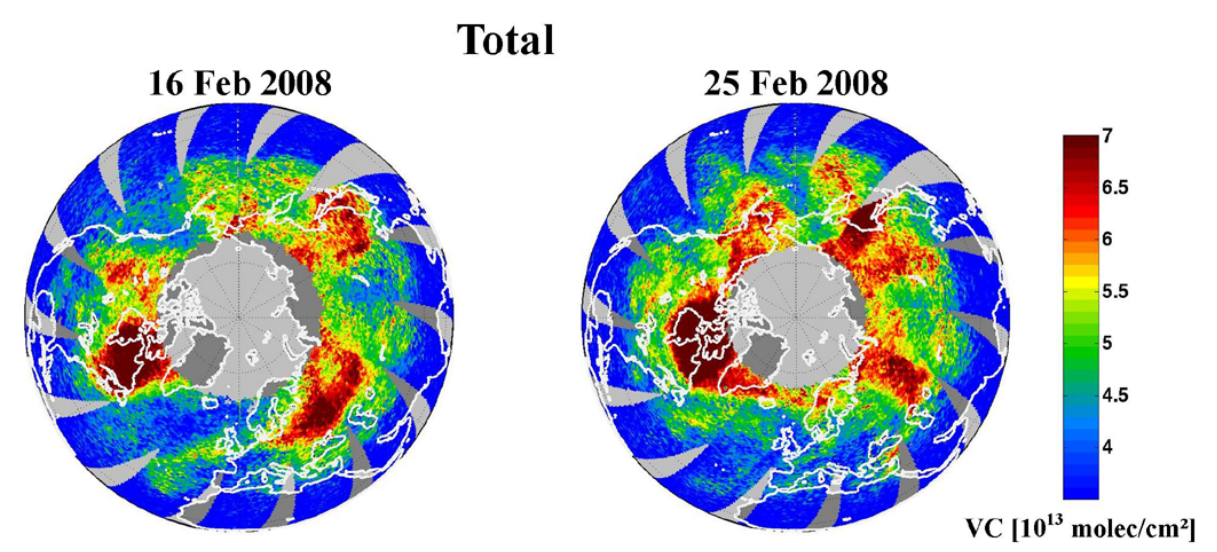

\section{Stratospheric}
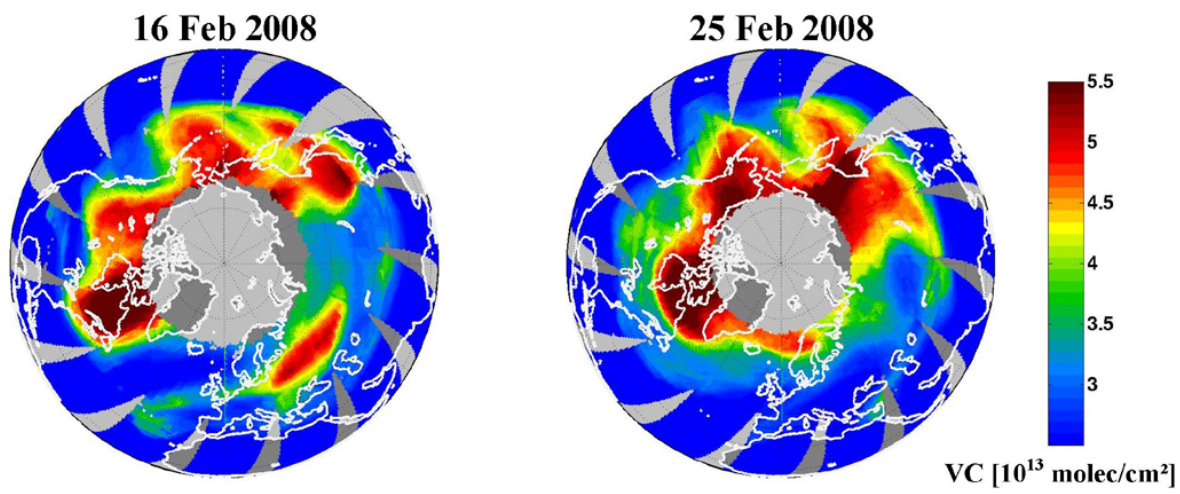

Total minus
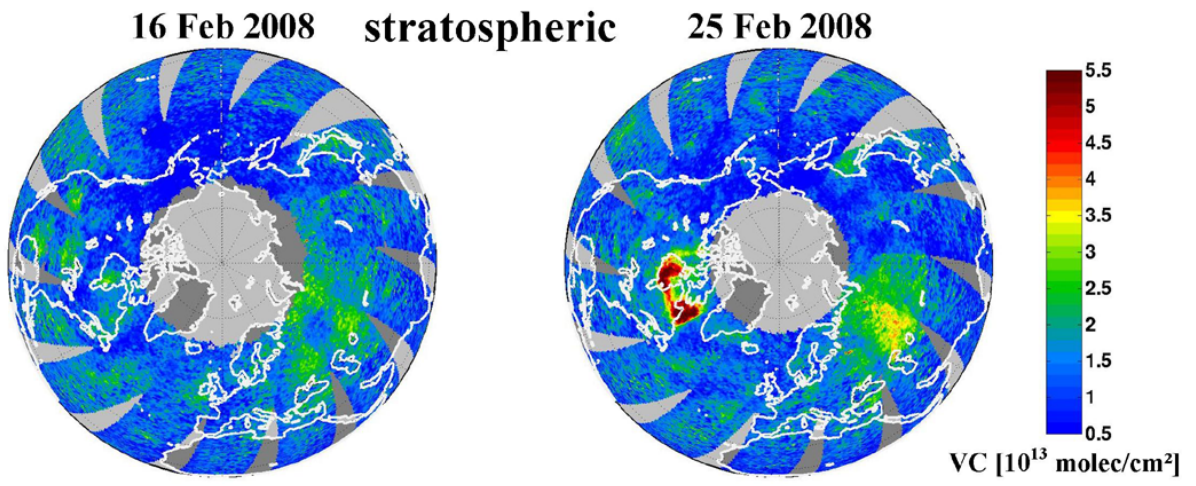

Fig. 9. GOME-2 total BrO columns (upper plots), stratospheric BrO columns calculated from the BASCOE climatology at GOME-2 overpass (center plots) and the difference between the total and stratospheric BrO columns (lower plots). Total BrO columns are estimated using stratospheric air mass factors. The results are presented for the (left) 16 and (right) 25 February 2008. Note that the color scale of the total column maps has been chosen in a way that the correlation with stratospheric $\mathrm{BrO}$ structures can be best visualized, although it is not optimal to represent the large range of total $\mathrm{BrO}$ column values.

vertical columns derived from our climatology, for two days in February 2008 in the Northern Hemisphere. The data of 16 February 2008 (left plots) have been selected because large-scale dynamical structures of stratospheric origin are observed in the measured total $\mathrm{BrO}$ map and at the same time the influence of tropospheric $\mathrm{BrO}$ on the measurements is moderate (absence of large and persistent plumes of tropospheric $\mathrm{BrO}$ ). One can see that the stratospheric $\mathrm{BrO}$ cli- matology qualitatively reproduces very well the dynamical structures of stratospheric $\mathrm{BrO}$ observed by the satellite. This is further confirmed when examining the map of the difference between the total and stratospheric columns. No evidence of remaining structures can be found beyond the range of observed background values. The data of 25 February 2008 in Fig. 9 (right plots) reflect another typical situation: in addition to the large-scale stratospheric $\mathrm{BrO}$ structures 
(consistently reproduced by the climatology), patterns of elevated tropospheric $\mathrm{BrO}$ columns are also observed in the vicinity of the Hudson Bay and the Caspian Sea. These structures show only little correlation with the simulated stratospheric $\mathrm{BrO}$ field and therefore can not be explained by a mismatch in the stratospheric $\mathrm{BrO}$ correction. The results of Fig. 9 are important not only because they consolidate our inversion approach, but also because they allow to address new issues, some of them already raised in previous papers: (1) the free tropospheric $\mathrm{BrO}$ background at mid-latitudes might be at least partly caused by transport of $\mathrm{BrO}$ enriched air masses from the polar boundary layer (Hollwedel, 2005), (2) a number of elevated total $\mathrm{BrO}$ columns observed from satellite instruments during Arctic spring can have stratospheric origin (Salawitch et al., 2010). Clearly such topics can only be studied properly by separating the stratospheric and tropospheric $\mathrm{BrO}$ structures in the total $\mathrm{BrO}$ column field measured from space.

Figure 10 presents an illustration of events typically observed in the Arctic spring. Total, stratospheric and tropospheric $\mathrm{BrO}$ columns measured in the Northern Hemisphere are represented over a period of three days in April 2008. Also shown are the corresponding tropopause heights. In this case, the full inversion scheme described in Sect. 3 has been used to determine the tropospheric and stratospheric $\mathrm{BrO}$ columns. Several features can be observed. First, the stratospheric $\mathrm{BrO}$ columns anti-correlate with the tropopause height field, the largest stratospheric $\mathrm{BrO}$ columns being found (as expected) at low tropopause height. Secondly, some of the total BrO column hotspots seen by GOME-2 exhibit spatial patterns similar to model estimates of stratospheric BrO column. These results are consistent with those reported by Salawitch et al. (2010). However, there are also regions of enhanced total $\mathrm{BrO}$ columns that are located in areas with low stratospheric BrO. We attribute this enhancement unambiguously to tropospheric BrO. Finally, a closer look to the $\mathrm{BrO}$ column results shows that several $\mathrm{BrO}$ hotspots are observed in both stratospheric and tropospheric fields. In the following, we investigate several explanations for this behaviour.

Although our stratospheric correction accounts for changes in tropopause heights (through its ozone column dependence), the stratospheric $\mathrm{BrO}$ columns may occasionally deviate from the climatological values for special conditions (e.g., extremely low tropopauses typically down to $5-6 \mathrm{~km}$ height). In such cases, a possible underestimation of the stratospheric $\mathrm{BrO}$ column results, leading to an overestimation of the tropospheric $\mathrm{BrO}$ columns, cannot be excluded. We have estimated this effect by calculating an upper limit of the difference between the stratospheric $\mathrm{BrO}$ columns from the climatology and from the BASCOE model run used to generate the climatological dataset (Theys et al., 2009b), for the conditions of $\mathrm{BrO}$ enriched descending air. When considering also the BrO column amount possibly transported below the tropopause by an intrusion of strato- spheric air in the troposphere, one estimates errors in the range of $1 \times 10^{13} \mathrm{molec} \mathrm{cm}^{-2}$. By inspecting the results of Fig. 10 over the Hudson Bay region $\left(55-70^{\circ} \mathrm{N}, 70-96^{\circ} \mathrm{W}\right)$ in conditions of very low tropopause heights, one can see that the retrieved tropospheric $\mathrm{BrO}$ columns in some instances do not exceed the surrounding tropospheric $\mathrm{BrO}$ background by more than this limit. This means that for these particular conditions, we cannot fully exclude that the enhancement of total $\mathrm{BrO}$ amount measured might be of stratospheric origin (either explained by a mismatch in the stratospheric $\mathrm{BrO}$ correction or by a stratospheric $\mathrm{BrO}$ intrusion). This is in line with the interpretation of the satellite total column $\mathrm{BrO}$ given by Salawitch et al. (2010). We have investigated the frequency of occurrence of such features for the spring season over the Hudson Bay area $\left(55-70^{\circ} \mathrm{N}, 70-96^{\circ} \mathrm{W}\right)$ and for the Northern high latitudes $\left(55-90^{\circ} \mathrm{N}\right)$ in general. For this purpose, we have considered in our analysis only the satellite "BrO hotspots", defined as the regions where total column $\mathrm{BrO}$ is elevated by at least $2 \times 10^{13} \mathrm{molec}^{-2}$ relative to the zonal mean (Salawitch et al., 2010). We have also defined a criterion to select the "events of possible stratospheric origin" among these measurements. The latter criterion is based on the retrieved residual $\mathrm{BrO}$ vertical columns. We consider that if the retrieved value is lower than a certain threshold then it is difficult to conclude whether there is an enhanced amount of $\mathrm{BrO}$ in the troposphere, and therefore a stratospheric event is a possible explanation. The limit chosen is $3.5 \times 10^{13} \mathrm{molec} \mathrm{cm}^{-2}$. This value is equal to the averaged tropospheric $\mathrm{BrO}$ column $\left(\sim 2.5 \times 10^{13} \mathrm{molec} / \mathrm{cm}^{2}\right)$ for the observations where a stratospheric event is unlikely (ozone columns $<350 \mathrm{DU}$ ) plus the uncertainty on the stratospheric correction of $1 \times 10^{13}$ molec cm$^{-2}$ (already introduced above). The results are displayed in Fig. 11, where we show the histograms of the retrieved tropospheric $\mathrm{BrO}$ vertical columns for the Northern high-latitudes and over the Hudson Bay. The data are from February to May (2007 and 2008); the tropospheric column threshold of $3.5 \times 10^{13}$ molec cm $^{-2}$ is also shown (brown dashed-line). The black and red curves correspond to the frequency distributions for $\mathrm{O}_{3}$ columns lower or larger than $450 \mathrm{DU}$, respectively, while the blue lines represent all measurements. From Fig. 11, it is clear that a stratospheric event can only be observed for sufficiently large $\mathrm{O}_{3}$ columns. This is what we expect as high ozone column is a prerequisite for a stratospheric BrO intrusion. Based on Fig. 11, one can also say that the stratospheric events are not very frequent for the Northern high-latitudes; the percentage of observations with tropospheric $\mathrm{BrO}$ columns lower than the threshold (brown dashed-line) is about $10 \%$ for ozone columns larger than $450 \mathrm{DU}$ and $3 \%$ in general. However, this behaviour is more frequent over the Hudson Bay region where the frequency is $20 \%$ for ozone columns larger than $450 \mathrm{DU}$ and $10 \%$ if no distinction based on ozone column is made. 


\section{Total BrO VCD}
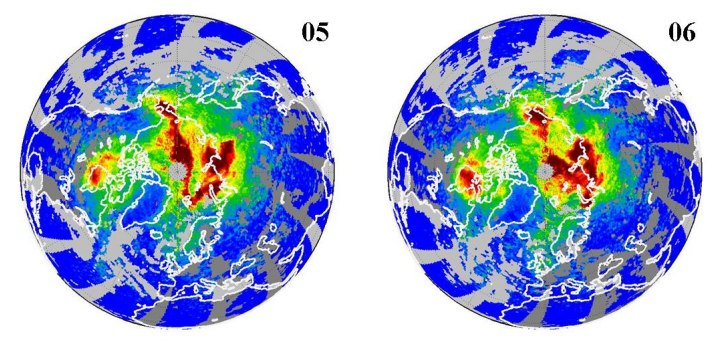

\section{April 2008}

\section{Stratospheric BrO VCD}
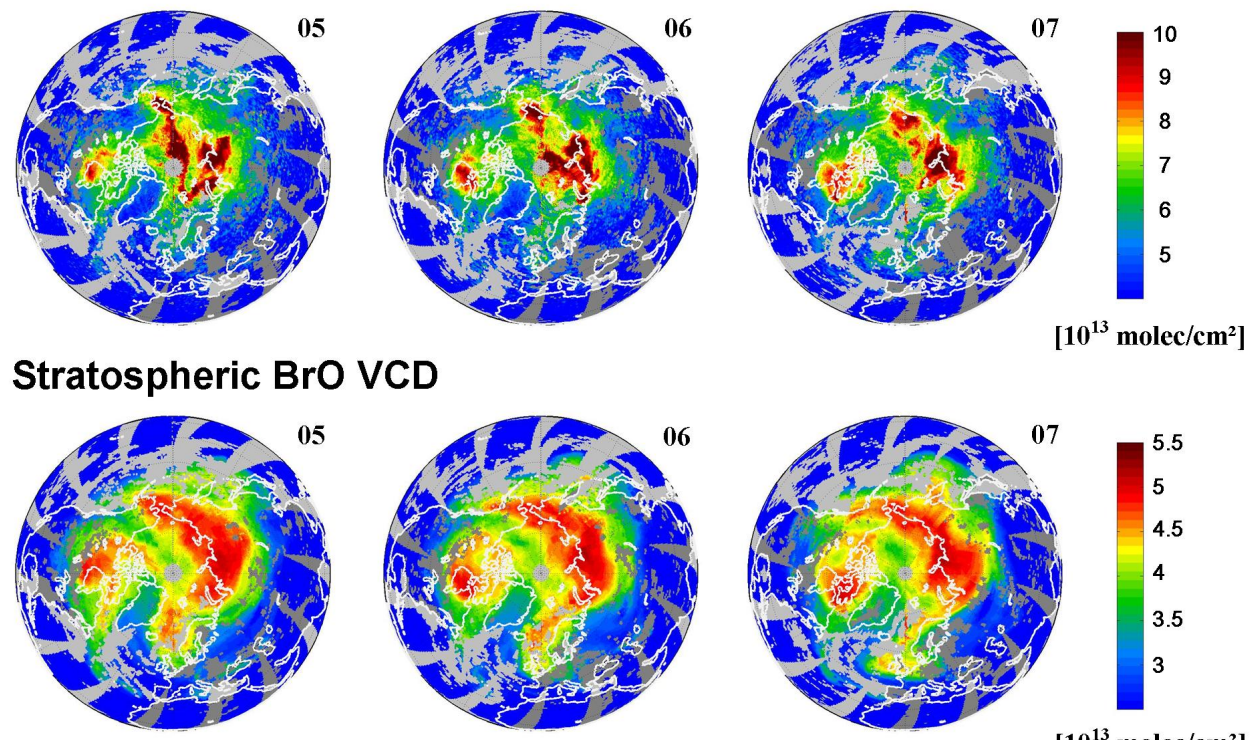

Tropospheric BrO VCD
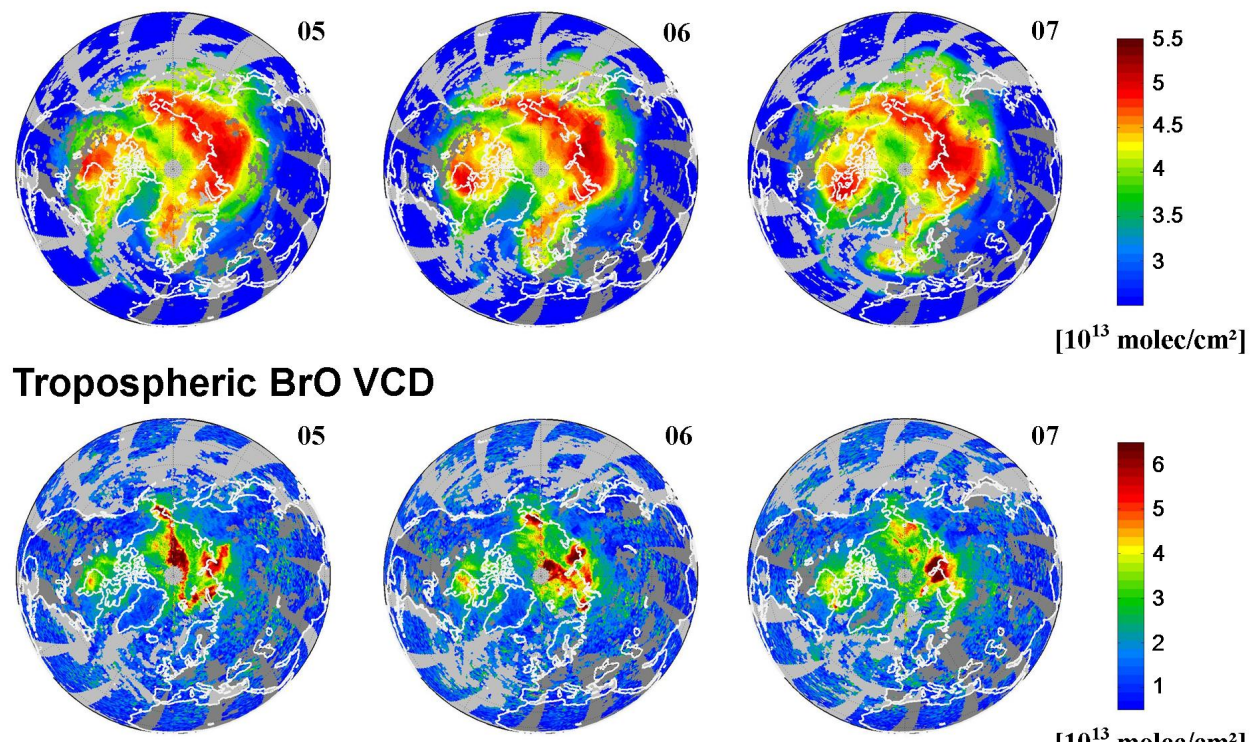

\section{Tropopause height}
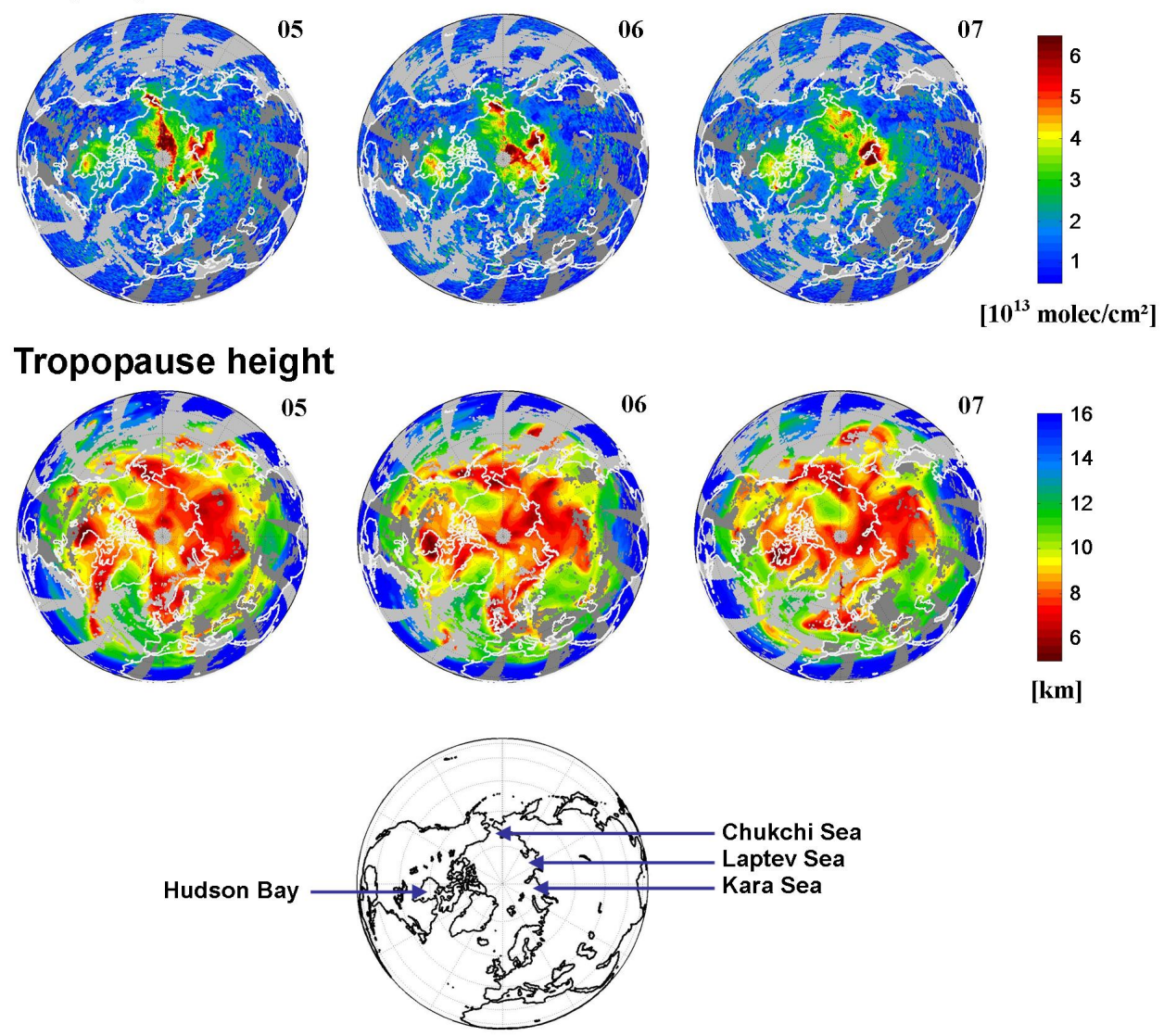

Fig. 10. GOME-2 BrO columns (total, stratospheric and tropospheric) and tropopause height (from ECMWF data). The results are presented for selected days in April 2008 (5 to 7 April, from left to right) in the Northern Hemisphere. The regions contaminated by clouds have been left in grey. 

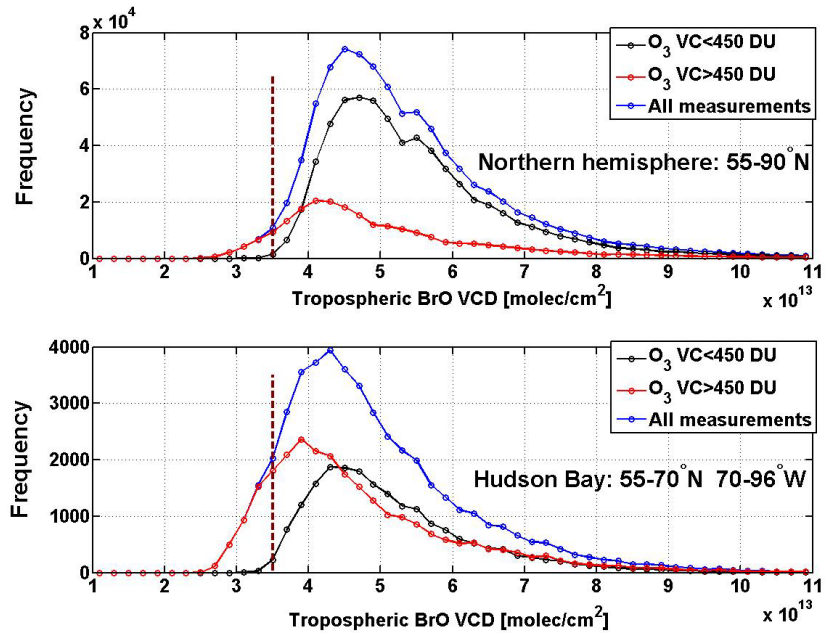

Fig. 11. Histograms of GOME-2 tropospheric BrO vertical columns for the satellite "BrO hostpots" observations (regions where $\mathrm{BrO}$ total columns are elevated by at least $2 \times 10^{13}$ molec $\mathrm{cm}^{-2}$ relative to the zonal mean). The data from February to May (2007 and 2008) are considered for (upper plot) the Northern Hemisphere $\left(55-90^{\circ} \mathrm{N}\right)$ and (lower plot) the Hudson Bay $\left(55-70^{\circ} \mathrm{N}, 70-96^{\circ} \mathrm{W}\right)$. Black and red lines show the frequency distributions of data with $\mathrm{O}_{3}$ vertical columns lower and higher than 450 Dobson Units, respectively. Blue lines: no distinction is made. The brown vertical dashed line corresponds to the upper limit of the residual tropospheric $\mathrm{BrO}$ vertical columns for the events of possible of stratospheric origin (see text).

It should be noted that all these percentage values represent upper limits of the frequency of stratospheric events, since they also include weak or localized tropospheric BrO events.

\subsection{Polar tropospheric BrO}

Let us examine the results of Fig. 10 for low tropopause heights in regions like the Laptev and Kara Seas (north of the Siberian coasts) and the Chukchi Sea (close to the Bering Strait). It can be seen that some (but not all) low tropopause areas in theses regions are collocated with tropospheric $\mathrm{BrO}$ hotspots. However, the residual columns of these tropospheric $\mathrm{BrO}$ hotspots are too high to be explained solely by a stratospheric effect (according to the above discussion). Therefore, it is likely that these tropospheric $\mathrm{BrO}$ hotspots are related to $\mathrm{BrO}$ precursors emissions at the surface.

We have further investigated the link between low tropopause heights and elevated tropospheric BrO columns (already discussed in Begoin et al., 2010). Figure 12 (upper plots) shows the frequency distribution of the results as a function of the tropopause height (for different values of tropospheric BrO vertical columns), for the 20072008 period in both Arctic and Antarctic regions. One can see that the distribution of data is clearly shifted towards low tropopause heights when the tropospheric $\mathrm{BrO}$ verti- cal columns increase, albeit large tropospheric $\mathrm{BrO}$ events are frequently observed under conditions of high tropopause. Sensitivity tests have been carried out in order to estimate the impact of a stratospheric BrO column error of $\pm 20 \%$ on the retrieved tropospheric columns. This leads only to a slight change of the frequency distribution of the results displayed in Fig. 12. This effect appears as a common behaviour in polar spring, although it seems to be more important in the Arctic than in the Antarctic region. We speculate that this feature might be connected to a relation between the tropopause height (linked to weather systems) and essential variables for $\mathrm{BrO}$ generation in the polar troposphere (e.g., temperature, illumination, availability of surfaces for heterogeneous reactions, etc.). One possible explanation could be a dynamically driven bromine emission mechanism: low tropopause is frequently associated to low pressure cyclone systems and strong surface winds. Recent studies (Yang et al., 2008 and 2010; Jones et al., 2009 and 2010) have provided convincing indications that the production of sea salt aerosol from snow lying on sea ice during blowing snow events (triggered by very strong surface winds) and the subsequent release of bromine, could be an important contribution to the bromine explosion phenomenon in the polar regions (Arctic and Antarctic). In order to investigate whether our analysis reflects this process assumed for bromine explosions, we have compared results of Fig. 12 to simulations from the $p$-TOMCAT model. $p$-TOMCAT (parallelTropospheric Off-Line Model of Chemistry and Transport) is an off-line three-dimensional tropospheric chemical transport model with a detailed bromine chemistry scheme that contains gas-phase reactions and heterogeneous reactions on cloud particles and aerosols, as well as bromine removal from dry and wet deposition (Yang et al., 2005, 2008 and 2010). It includes bromine emissions from sea salt, bromocarbon photo-oxidation and also a parameterization for sea salt aerosol production through blowing snow events (in the latest version of $p$-TOMCAT; see Yang et al., 2010). For the present study, the model was run for the 2007-2008 period at a horizontal resolution of $2.8^{\circ} \times 2.8^{\circ}$ and an output frequency of $2 \mathrm{~h}$ using winds and temperature derived from the ECMWF operational analysis. For each grid box, we have calculated a daily maximum tropospheric BrO column based on the modelled $\mathrm{BrO}$ profiles and a corresponding dynamical tropopause height (using the definition of the dynamical tropopause in Sect. 3.2). Using this modelling data set, we have done the same statistical analysis as for GOME-2 data; the results are presented in Fig. 12 (lower plots). One can clearly identify similarities in both hemispheres between the modelling and the retrieved results for the distribution of the tropospheric $\mathrm{BrO}$ columns as a function of the tropopause height. The general tendency of elevated tropospheric BrO columns linked to low tropopause heights being well captured by the $p$-TOMCAT model. It should be noted that the model definitely fails to reproduce the observed features when the blowing snow-sourced bromine is omitted (in line 

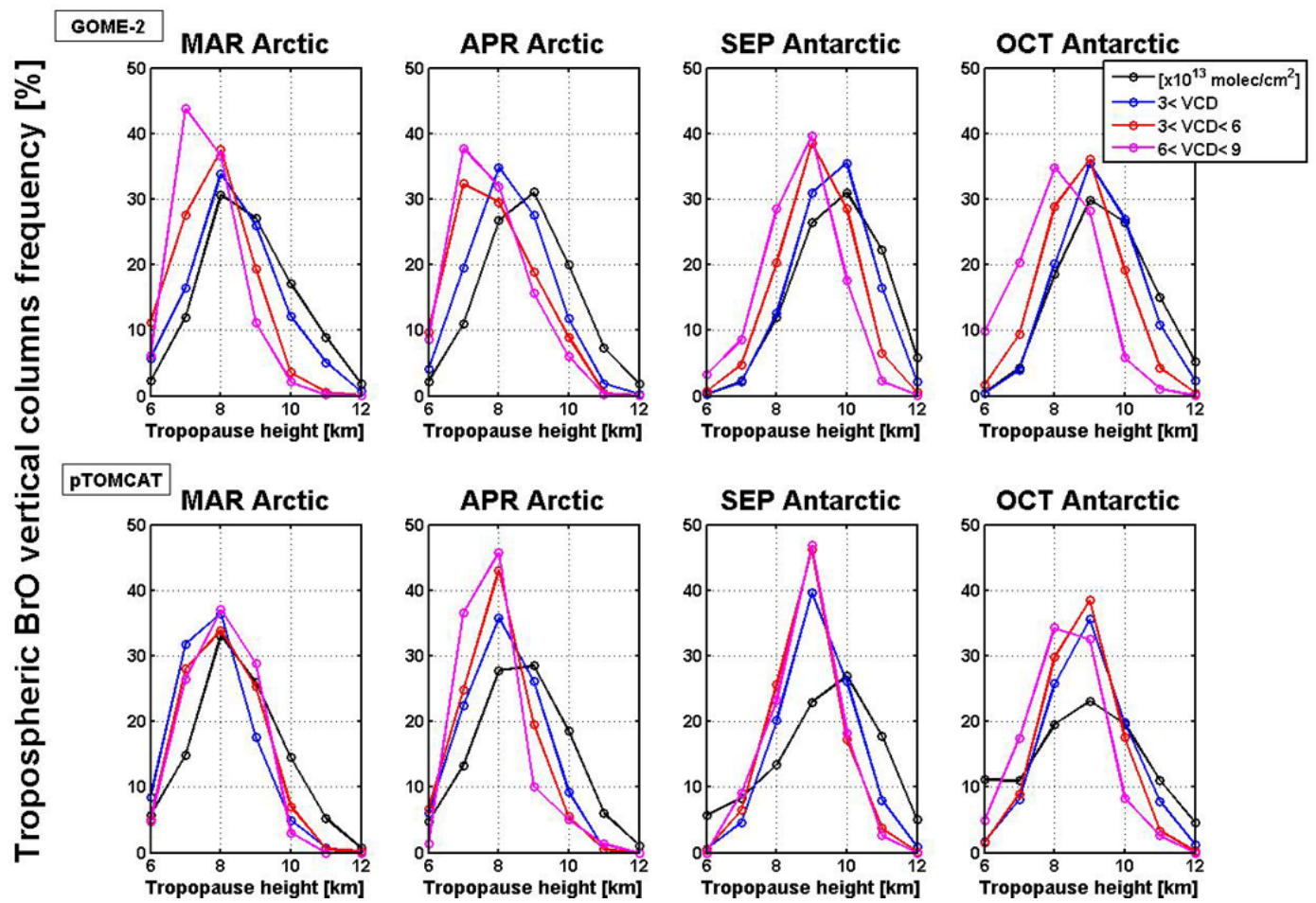

Fig. 12. Frequency distribution (expressed in \%) of the GOME-2 (upper row) and p-TOMCAT (lower row) tropospheric BrO vertical columns as a function of the altitude of the tropopause $( \pm 0.5 \mathrm{~km})$, for different ranges of vertical columns. The results are shown separately for different months in spring in the Northern Hemisphere (55-90 N; March and April) and Southern hemisphere (55-75 ${ }^{\circ}$; September and October). Only data corresponding to solar zenith angles lower than $80^{\circ}$ are considered here.

with the findings of Yang et al., 2010). The results of Fig. 12 provide an indication that the release of bromine by blowing snow events might play a role in the bromine explosion phenomenon, in both the Arctic and Antarctic. However, one should be cautious with this interpretation since other dynamically driven bromine production mechanisms may possibly lead to similar behaviour. It is also worth adding that in another recent study, Begoin et al. (2010) have used GOME2 data to study an event of long range transport of $\mathrm{BrO}$ plume in the Arctic lower troposphere in spring 2007. Using trajectory calculations, they found quite similar dynamics in the troposphere and lower stratosphere for this particular event. In particular the $\mathrm{BrO}$ hotspot of interest was clearly linked to the low tropopause heights. If this transport-related feature is frequent in the polar region, it can reinforce (and also complicate) the relation between low tropopause heights and high tropospheric $\mathrm{BrO}$ columns, as displayed in Fig. 12.

In order to further investigate the relevance of the blowingsnow mechanism, we present two examples of events (Fig. 13) found in the GOME-2 tropospheric BrO vertical column maps that are directly reproduced by the $p$ TOMCAT simulations (interpolated to the time and location of GOME-2 overpass). It shows clearly the generation of $\mathrm{BrO}$ plumes in the polar boundary layer over the Chukchi Sea (3-5 April 2008, Arctic) and the Ross Sea (22-
24 October 2007, Antarctic). Noteworthy is the good coincidence in magnitude, space and time between GOME-2 and $p$-TOMCAT tropospheric $\mathrm{BrO}$ plumes. Both events are associated to strong surface winds and can only be explained by including the blowing snow mechanism in the $p$-TOMCAT model. Both $\mathrm{BrO}$ plumes are confined in the polar boundary layer (below $1.5 \mathrm{~km}$ height) with $\mathrm{BrO}$ mixing ratios as high as 30 pptv. Although the results of Fig. 13 can be reasonably well explained by the mechanism of bromine release from blowing snow events, they provide no indication on the precise magnitude of this blowing snow source compared to other processes. It should also be emphasized that beyond the cases displayed in Fig. 13, there are also large discrepancies between the model and the measurements. This is either due to the fact that the $p$-TOMCAT Br emission is highly parameterized (the limiting uncertainties coming from the snow salinity and the fraction of bromine in sea salt aerosol which is released in gaseous form into the atmosphere - the bromine depletion factor; see Yang et al., 2010) and/or that other possible bromine sources are missing in the model.

Nevertheless, the results presented here call for further modelling developments supported by satellite $\mathrm{BrO}$ measurements and in-situ measurements during blowing snow events in order to better assess the relative contributions of bromine sources in the polar troposphere. Though it goes far beyond 


\section{Tropospheric BrO VC}
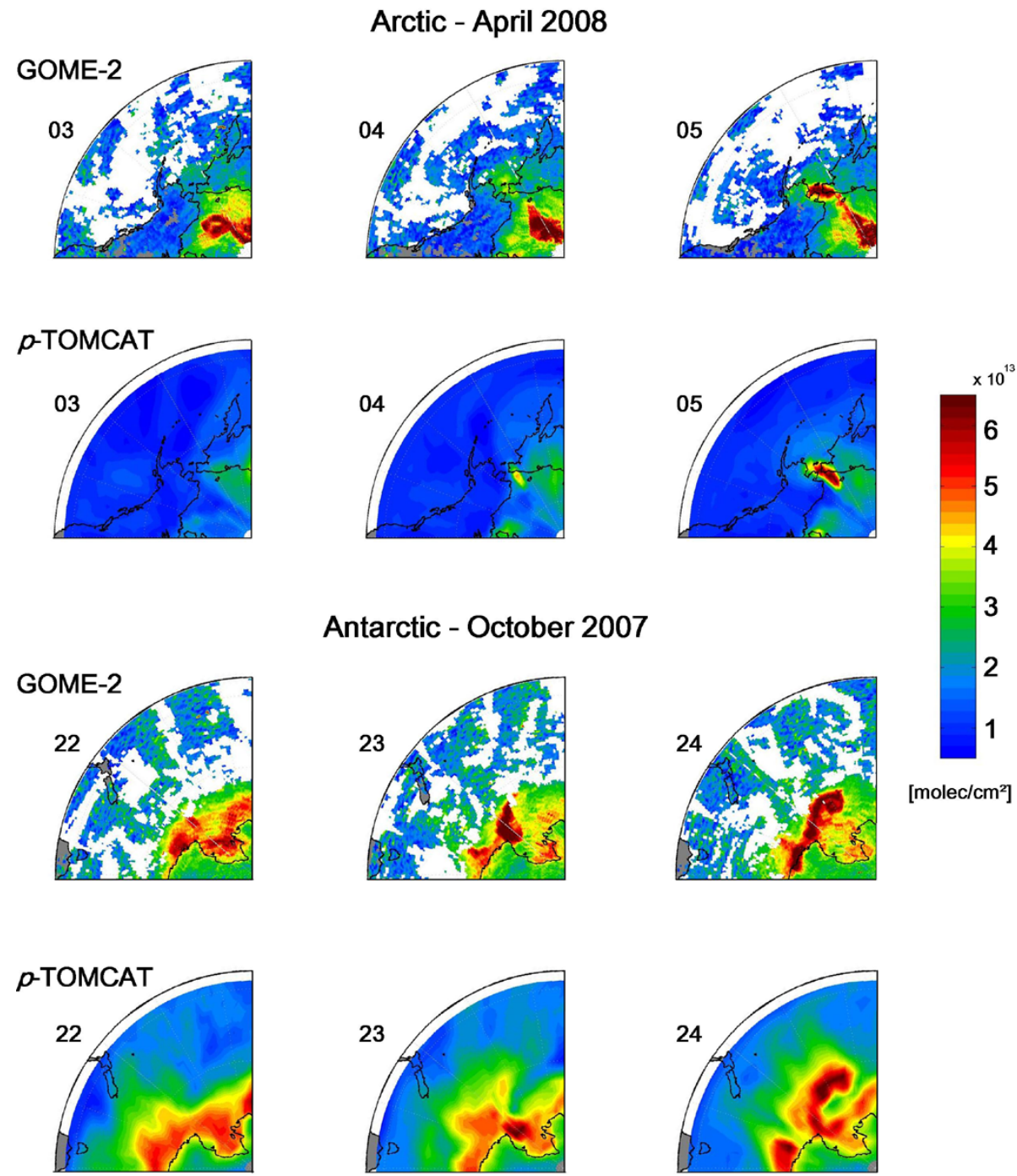

Fig. 13. Tropospheric BrO vertical columns from GOME-2 and $p$-TOMCAT across the Chukchi Sea region of Arctic from 3 to 5 April 2008 (upper panels) and over the Ross Sea of Antarctica from 22 to 24 October 2007 (lower panels).

the scope of this paper, this is of great importance especially to better assess future tropospheric bromine emissions in response to climate change (Arctic warming, increase of first year sea ice coverage and increase of anthropogenic emissions, e.g. from shipping).

\subsection{Extra-polar tropospheric BrO}

Turning to global fields, we now investigate the latitudinal and seasonal variations of the retrieved tropospheric $\mathrm{BrO}$ vertical columns. For this purpose, monthly averages of tropospheric BrO columns have been computed for different latitudinal bands in both hemispheres. The results are presented in Fig. 14, together with estimates of the corresponding retrieval errors that include all sources of uncer- tainties (details are given in Sect. 3.4). We have also plotted the variability of the data $(1 \sigma)$ within each latitudinal band and month. It is important to note the large variability of the resulting tropospheric vertical columns. Although a fraction of this variability originates from the natural variability of tropospheric $\mathrm{BrO}$ (e.g. during spring at high latitudes), an important part of the observed variations results from the propagation of the instrumental noise through the DOAS analysis. When averaging (as in Fig. 14), the random error is largely reduced and the total error on the averaged tropospheric $\mathrm{BrO}$ vertical columns is dominated by systematic errors. The latter errors (grey-dashed area) are estimated to be in the range from $1 \times 10^{13}$ molec $\mathrm{cm}^{-2}$ in summer to $1.5-2 \times 10^{13}$ molec $\mathrm{cm}^{-2}$ in winter. From Fig. 14, it can be 

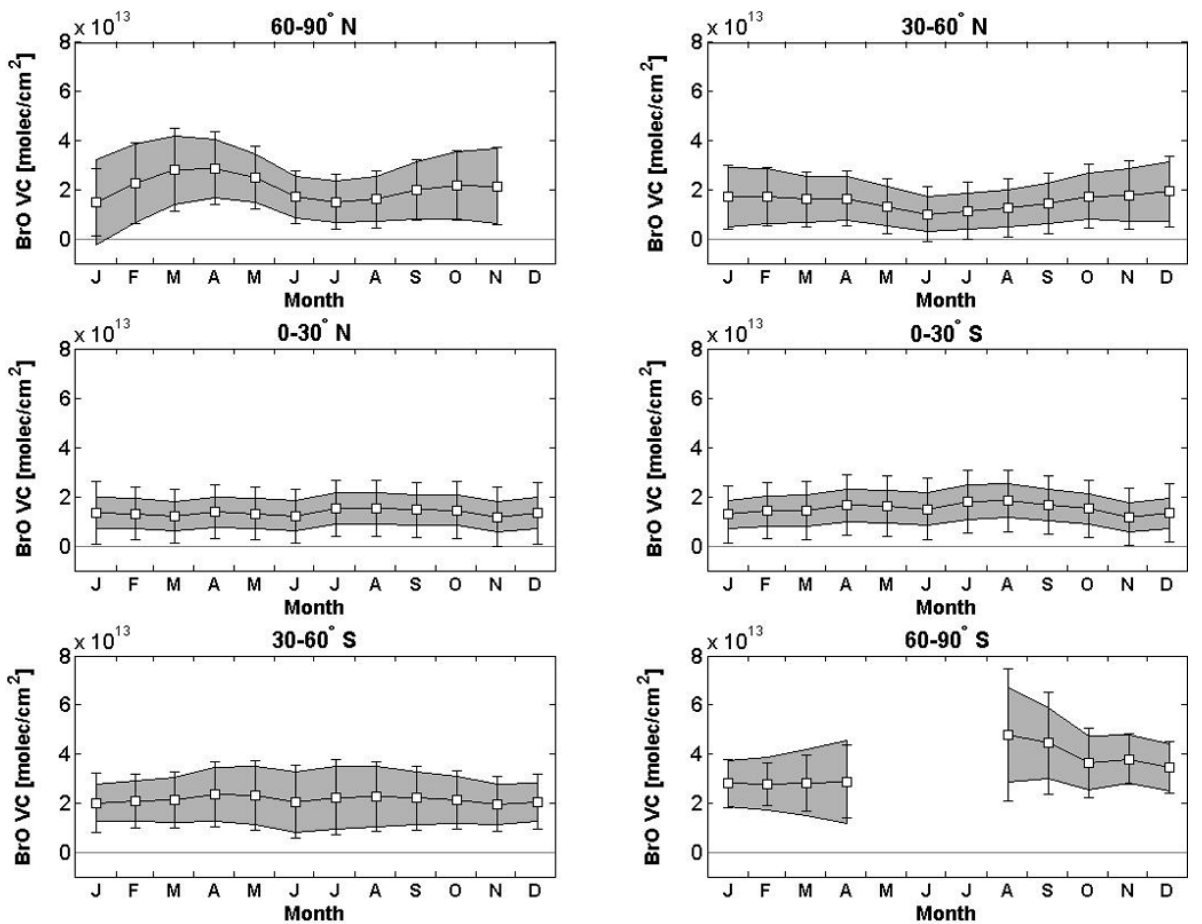

Fig. 14. Zonal mean of tropospheric BrO vertical columns as a function of time (monthly averages). The grey-dashed area indicates the total error on the tropospheric BrO vertical columns (see text). The error bars correspond to 1-sigma standard deviation of the data around the mean. The data used are from 2007 to 2008 , and solar zenith angles lower than $80^{\circ}$.

stated that, except for the results at high latitudes in spring, the seasonal and latitudinal variations of the tropospheric $\mathrm{BrO}$ columns are generally rather small, with a magnitude lying within the uncertainties of the retrieved tropospheric $\mathrm{BrO}$ columns. Our analysis tends to confirm the findings of other studies (Fitzenberger et al., 2000; Wagner et al., 2001; Richter et al., 2002; Van Roozendael et al., 2002; Hendrick et al., 2007; Theys et al., 2007) that a tropospheric BrO background with vertical columns of $1-3 \times 10^{13} \mathrm{molec} \mathrm{cm}^{-2}$, in addition to the polar $\mathrm{BrO}$ emissions occurring in spring, must be present at the global scale for all seasons. This is in contrast to three studies using spectral observations of direct-sun geometry, at Lauder (Schofield et al., 2004), Arrival Heights, Antarctica (Schofield et al., 2006) and in the tropics (Dorf et al., 2008) showing tropospheric columns significantly less i.e. $0.2-0.3 \times 10^{13}$ molec $\mathrm{cm}^{-2}$ and tropospheric $\mathrm{BrO}$ mixing ratios lower than $1 \mathrm{pptv}$, respectively, indicating that more study is required on this subject.

We have further tested the assumption of a significant tropospheric $\mathrm{BrO}$ background by making use of GOME-2 cloudy pixels, with the aim to obtain an independent estimate of the $\mathrm{BrO}$ content in the troposphere. The approach is similar in concept to the one used to derive tropospheric ozone from the TOMS satellite instrument ("Cloud slicing"; Ziemke et al., 2001). This technique takes benefit of the opaque property of clouds to UV radiation and the enhanced measurement sensitivity above the cloud-top (see Fig. 4, purple curve). As the measurement sensitivity vanishes below the cloud, larger tropospheric $\mathrm{BrO}$ slant columns should be measured for lower clouds, if a substantial amount of $\mathrm{BrO}$ is present in the troposphere. This is precisely what is observed in Fig. 15 which shows the correlation between tropospheric $\mathrm{BrO}$ slant columns (cloud fractions $>70 \%$ ) from GOME-2 measurements (taken in December as an example) and the collocated cloud top pressure (from FRESCO+). In order to scan vertically an important portion of the troposphere, we have selected the data over the tropical latitude band $\left(30^{\circ} \mathrm{S}-30^{\circ} \mathrm{N}\right)$. This is justified by the fact that some clouds associated to convective processes can reach much higher altitudes in the tropical region than at other latitudes. In Fig. 15, tropospheric $\mathrm{BrO}$ slant columns range roughly from zero at $200 \mathrm{hPa}$ to about $5 \times 10^{13}$ molec cm $^{-2}$ at ground level $(1000 \mathrm{hPa})$. One can see that most of the $\mathrm{BrO}(>75 \%)$ is present in the atmospheric layers above $700 \mathrm{hPa}$, i.e. in the freetroposphere. Considering the $\mathrm{BrO}$ slant column increment of $5 \times 10^{13} \mathrm{molec} \mathrm{cm}^{-2}$ in the tropical troposphere, it is possible to calculate an average tropospheric vertical column by applying an effective above-cloud tropospheric AMF (AMF $\sim 3-3.5$, according to Fig. 4). This leads to a tropospheric $\mathrm{BrO}$ vertical column of about $1.5 \times 10^{13}$ molec cm $\mathrm{cm}^{-2}$, which is in reasonable agreement with the estimated values for the tropospheric $\mathrm{BrO}$ background vertical column obtained throughout this work (Figs. 6, 7 and 14) and the BrO column 


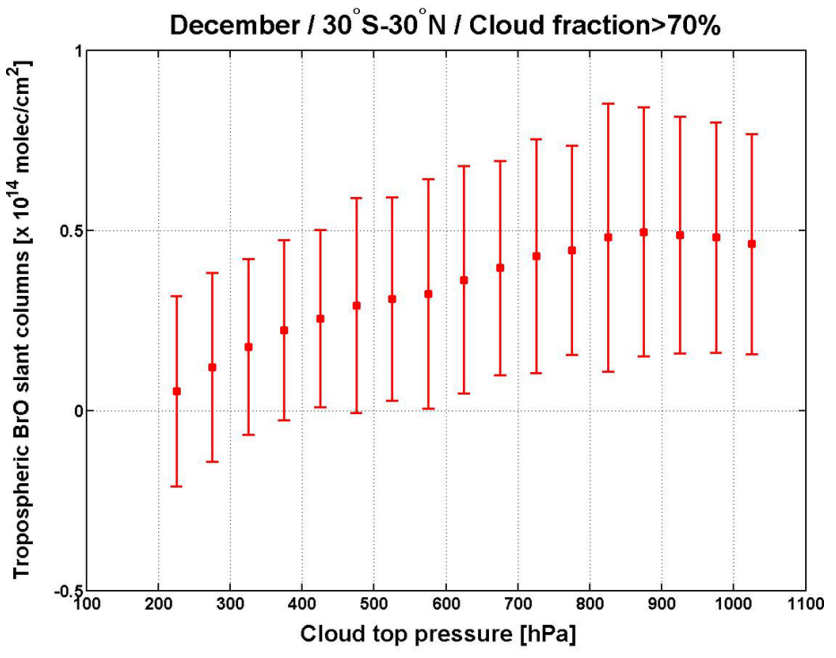

Fig. 15. GOME-2 tropospheric BrO slant columns as a function of cloud top pressure (cloud fraction $>70 \%$ ), in December for $-30^{\circ} \leq$ latitude $\leq 30^{\circ}$. The red squares correspond to the mean tropospheric BrO SCD values for cloud top pressure bins of $50 \mathrm{hPa}$, and the error bars represent the variability of the column within each bin $(1 \sigma)$.

amount of about $1.1 \pm 0.45 \times 10^{13}$ molec cm $^{-2}$ inferred from ground-based multi-axis DOAS measurements in Reunion Island (Theys et al., 2007). It should be noted that similar results were reported by Richter et al. (2002) based on an analysis of the correlation between $\mathrm{BrO}$ and $\mathrm{O}_{4}$ slant columns from the GOME instrument.

\section{Conclusions}

We have developed an algorithm to retrieve tropospheric $\mathrm{BrO}$ columns from satellite nadir UV/visible radiance measurements. The tropospheric columns are derived from a residual technique that combines measured DOAS slant columns and calculated stratospheric columns, and that accounts for the impact of clouds, surface reflectivity and viewing geometry on the measurement sensitivity. The stratospheric $\mathrm{BrO}$ correction makes use of a recently developed dynamical climatology of stratospheric $\mathrm{BrO}$ (Theys et al., 2009b). This climatology has been generated using $\mathrm{BrO}$ profiles from the BASCOE three-dimensional chemical transport model, which includes a contribution of 6 pptv to the stratospheric $\mathrm{Br}_{\mathrm{y}}$ budget from short-lived brominated sources gases. Moreover, model simulations have been extensively validated through comparison with several independent correlative data sets of stratospheric $\mathrm{BrO}$ observations.

We have successfully applied this algorithm to two years (2007-2008) of data from the GOME-2 instrument, analyzed using improved DOAS settings. The consistency between our $\mathrm{BrO}$ retrieval and correlative data has been verified and a good agreement has been obtained with SCIAMACHY nadir observations and ground-based zenith-sky observations. We have demonstrated that our method enables to separate the stratospheric and tropospheric $\mathrm{BrO}$ structures in the total $\mathrm{BrO}$ column field measured from space. Hence it results in a refined and more quantitative interpretation of the nadir $\mathrm{BrO}$ observations. In line with the findings of Salawitch et al. (2010), we found that elevated total column BrO observations in polar spring can occasionally be explained by an increase in stratospheric $\mathrm{BrO}$ column due to tropopause descend, and a possible stratospheric intrusion of $\mathrm{BrO}$ into the free-troposphere. However, the strong polar $\mathrm{BrO}$ hotspots observed, which, interestingly, are often associated to low tropopause heights, cannot be explained by an influence of stratospheric air only. Supported by simulations from the $p$ TOMCAT tropospheric chemical transport model (Yang et al., 2010), we have investigated more systematically the relationship between high retrieved tropospheric $\mathrm{BrO}$ columns and low tropopause heights in the polar region, and we found a plausible explanation for it by considering the release of bromine through the production of sea salt aerosols during blowing snow events (linked to low pressure systems). However, no firm conclusions can be drawn from our analysis on the relative importance of such mechanism on the polar bromine explosion events. Outside the polar region, it is found that the tropospheric $\mathrm{BrO}$ columns retrieved using our algorithm are consistent with the presence of a global $\mathrm{BrO}$ background at free tropospheric altitudes, with columns of $1-3 \times 10^{13}$ molec $\mathrm{cm}^{-2}$, in agreement with results from other studies.

Acknowledgements. This research has been financially supported through the Belgium Prodex 9 contract SECPEA, the EUMETSAT O3M-SAF Continuous Development and Operation Project, the GEOmon (FP6-2005-Global-4-036677) and SHIVA (226224FP7-ENV-2008-1) projects from the European Commission. The authors acknowledge EUMETSAT for providing the GOME-2 level-1 data product and DLR-IMF for providing the GOME-2 operational product.

Edited by: J. W. Bottenheim

\section{References}

Afe O. T., Richter, A., Sierk, B., Wittrock, F., and Burrows, J. P.: BrO emissions from volcanoes: a survey using GOME and SCIAMACHY measurements, Geophys. Res. Lett., 31, L24113, doi:10.1029/2004GL0200994, 2004.

Aliwell, S. R., Van Roozendael, M., Johnston, P. V., Richter, A., Wagner, T., Arlander, D.W., Burrows, J. P., Fish, D. J., Jones, R. L., Tornkvist, K. K., Lambert, J. C., Pfeilsticker, K., and Pundt, I.: Analysis for $\mathrm{BrO}$ in zenith-sky spectra: An intercomparison exercise for analysis improvement, J. Geophys. Res., 107, D140, doi:10.1029/2001JD000329, 2002.

Begoin, M., Richter, A., Weber, M., Kaleschke, L., Tian-Kunze, X., Stohl, A., Theys, N., and Burrows, J. P.: Satellite observations of long range transport of a large $\mathrm{BrO}$ plume in the Arctic, 
Atmos. Chem. Phys., 10, 6515-6526, doi:10.5194/acp-10-65152010, 2010.

Bobrowski, N., Hönninger, G., Galle, B., and Platt, U.: Detection of bromine monoxide in a volcanic plume, Nature, 423, 273-276, 2003.

Boersma, K. F., Eskes, H. J., and Brinksma, E. J.: Error analysis for tropospheric $\mathrm{NO}_{2}$ retrieval from space, J. Geophys. Res., 109, D04311, doi:10.1029/2003JD003962, 2004.

Bogumil, K., Orphal, J., Homann, T., Voigt, S., Spietz, P., Fleischmann, O.C., Vogel, A., Hartmann, M., Bovensmann, H., Frerik, J., and Burrows, J. P.: Measurements of molecular absorption spectra with the SCIAMACHY Pre-Flight Model: Instrument characterization and reference spectra for atmospheric remote sensing in the $230-2380 \mathrm{~nm}$ region, J. Photochem. Photobiol. A, 157, 167-184, 2003.

Bovensmann, H., Burrows, J. P., Buchwitz, M., Frerick, J., Noël, S., Rozanov, V. V., Chance, K. V., Goede, A. P. H.: SCIAMACHY: Mission objectives and Measurement Modes, J. Atm. Sci., 56, 127-150, 1999.

Brion, J., Chakir, A., Daumont, D., and Malicet, J.: High-resolution laboratory absorption cross sections of $\mathrm{O}_{3}$, Temperature effect, Chem. Phys. Lett., 213(5-6), 610-612, 1993.

Burrows, J. P., Dehn, A., Deters, B., Himmelmann, S., Richter, A., Voigt, S., and Orphal, J.: Atmospheric Remote-Sensing Reference Data from GOME: 1. Temperature-Dependent Absorption Cross Sections of $\mathrm{NO}_{2}$ in the 231-794 nm Range, J. Quant. Spectrosc. Radiat. Transfer, 60, 1025-1031, 1998.

Chance, K.: Analysis of BrO measurements from the Global Ozone Monitoring Experiment, Geophys. Res. Lett., 25, 3335-3338, 1998.

De Smedt, I., Müller, J.-F., Stavrakou, T., van der A, R., Eskes, H., and Van Roozendael, M.: Twelve years of global observations of formaldehyde in the troposphere using GOME and SCIAMACHY sensors, Atmos. Chem. Phys., 8, 4947-4963, doi:10.5194/acp-8-4947-2008, 2008.

Dorf, M., Butz, A., Camy-Peyret, C., Chipperfield, M. P., Kritten, L., and Pfeilsticker, K.: Bromine in the tropical troposphere and stratosphere as derived from balloon-borne $\mathrm{BrO}$ observations, Atmos. Chem. Phys., 8, 7265-7271, doi:10.5194/acp-8-72652008, 2008

Errera, Q., Daerden, F., Chabrillat, S., Lambert, J. C., Lahoz, W. A., Viscardy, S., Bonjean, S., and Fonteyn, D.: 4D-Var assimilation of MIPAS chemical observations: ozone and nitrogen dioxide analyses, Atmos. Chem. Phys., 8, 6169-6187, doi:10.5194/acp8-6169-2008, 2008.

EUMETSAT, GOME-2 FM3 Calibration: Instrument Performance Testing, MO-TR-TPD-GO-0094, 2009.

Fitzenberger, R., Bösch, H., Camy-Peyret, C., Chipperfield, M. P., Harder, H., Platt, U., Sinnhuber, B.-M., Wagner, T., and Pfeilsticker, K.: First profile measurements of tropospheric BrO, Geophys. Res. Lett., 27, 2921-2924, 2000.

Fleischmann, O. C., Hartmann, M., Burrows J. P., and Orphal, J.: New ultraviolet absorption cross-sections of $\mathrm{BrO}$ at atmospheric temperatures measured by time-windowing Fourier transform spectroscopy, J. Photochem. Photobiol. A, 168, 117-132, 2004.

Frieß, U., Hollwedel, J., König-Langlo, G., Wagner, T., and Platt, U.: Dynamics and chemistry of tropospheric bromine explosion events in the Antarctic coastal region, J. Geophys. Res., 109, D06305, doi:10.1029/2003JD004133, 2004.
Grainger, J. F. and Ring, J.: Anomalous Fraunhofer lines profiles, Nature, 193, p. 762, 1962.

Harder, H., Camy-Peyret, C., Ferlemann, F., Fitzenberger, R., Hawat, T., Osterkamp, H., Perner, D., Platt, U., Schneider, M., Vradelis, P., and Pfeilsticker, K.: Stratospheric BrO Profiles Measured at Different Latitudes and Seasons: Atmospheric Observations, Geophys. Res. Lett., 25, 3843-3846, 1998.

Hausmann, M. and Platt, U.: Spectroscopic measurement of bromine oxide and ozone in the high Arctic during Polar Sunrise Experiment 1992, J. Geophys. Res., 99, 25399-25414, 1994.

Hebestreit, K., Stutz, J., Rosen, D., Matveiv, V., Peleg, M., Luria, M., and Platt, U.: DOAS measurements of tropospheric bromine oxide in mid-latitudes, Science, 283, 55-57, 1999.

Hendrick, F., Van Roozendael, M., Chipperfield, M. P., Dorf, M., Goutail, F., Yang, X., Fayt, C., Hermans, C., Pfeilsticker, K., Pommereau, J.-P., Pyle, J. A., Theys, N., and De Mazire, M.: Retrieval of stratospheric and tropospheric BrO profiles and columns using ground-based zenith-sky DOAS observations at Harestua, $60^{\circ} \mathrm{N}$, Atmos. Chem. Phys., 7, 4869-4885, doi:10.5194/acp-7-4869-2007, 2007.

Hendrick, F., Johnston, P. V., De Mazière, M., Fayt, C., Hermans, C., Kreher, K., Theys, N., and Van Roozendael, M.: Onedecade trend analysis of stratospheric $\mathrm{BrO}$ over Harestua $\left(60^{\circ} \mathrm{N}\right)$ and Lauder $\left(45^{\circ} \mathrm{S}\right)$ reveals a decline, Geophys. Res. Lett., 35, L14801, doi:10.1029/2008GL034154, 2008.

Hendrick, F., Rozanov, A., Johnston, P. V., Bovensmann, H., De Mazière, M., Fayt, C., Hermans, C., Kreher, K., Lotz, W., Sinnhuber, B.-M., Theys, N., Thomas, A., Burrows, J. P., and Van Roozendael, M.: Multi-year comparison of stratospheric $\mathrm{BrO}$ vertical profiles retrieved from SCIAMACHY limb and ground-based UV-visible measurements, Atmos. Meas. Tech., 2, 273-285, doi:10.5194/amt-2-273-2009, 2009.

Hollwedel, J.: Observations of Tropospheric and Stratospheric Bromine Monoxide from Satellite, PhD. Thesis, University of Heidelberg, Germany, 2005.

Hönninger, G. and Platt, U.: Observations of $\mathrm{BrO}$ and its vertical distribution during surface ozone depletion at Alert, Atmos. Environ., 36, 2481-2489, 2002.

Jones, A. E., Anderson, P., Begoin, M., Brough, N., Hutterli, M., Marshall, G., Richter, A., Roscoe, H., and Wolff, E.: BrO, blizzards, and drivers of polar tropospheric ozone depletion events, Atmos. Chem. Phys., 9, 4639-4652, 2009, http://www.atmos-chem-phys.net/9/4639/2009/.

Jones, A. E., Anderson, P., Wolff, E., Roscoe, H., Marshall, G., Richter, A., Brough, N., and Colwell, S.: Vertical structure of Antarctic tropospheric ozone depletion events: characteristics and broader implications, Atmos. Chem. Phys., 10, 7775-7794, 2010 , http://www.atmos-chem-phys.net/10/7775/2010/.

Kaleschke, L., Richter, A., Burrows, J. P., Afe, O., Heygster, G., Notholt, J., Rankin, A.M., Roscoe, H.K., Hollwedel, J., Wagner, T., and Jacobi, H.-W.: Frost flowers on sea ice as a source of sea salt and their influence on tropospheric halogen chemistry, Geophys. Res. Lett., 31, L16114, doi:10.1029/2004GL020655, 2004.

Koelemeijer, R. B. A., Stammes, P., Hovenier, J. W., and de Haan, J. F.: Global distributions of effective cloud fraction and cloud top pressure derived from oxygen A band spectra measured by the Global Ozone Monitoring Experiment: com- 
parison to ISCCP data, J. Geophys. Res., 107(D12), 4151, doi:10.1029/2001JD000840, 2002.

Koelemeijer, R. B. A., de Haan, J. F., and Stammes, P.: A database of spectral surface reflectivity in the range $335-772 \mathrm{~nm}$ derived from 5.5 years of GOME observations, J. Geophys. Res.-Atm., 108(D2), 4070, doi:10.1029/2002JD002429, 2003.

Kreher, K., Johnston, P. V., Wood, S. W., Nardi, B., and Platt, U.: Ground-based measurements of tropospheric and stratospheric BrO at Arrival Heights, Antarctica, Geophys. Res. Lett., 24, 3021-3024, 1997.

Lary, D. J.: Gas phase atmospheric bromine photochemistry, J. Geophys. Res., 101, 1505-1516, 1996.

Lary, D. J.: Halogens and the chemistry of the free troposphere, Atmos. Chem. Phys., 5, 227-237, doi:10.5194/acp-5-227-2005, 2005.

Leser, H., Höninger, G., and Platt, U.: Max-DOAS measurements of $\mathrm{BrO}$ and $\mathrm{NO}_{2}$ in the marine boundary layer, Geophys. Res. Lett., 30, 1537, doi:10.1029/2002GL015811, 2003.

Martin, R. V., Chance, K., Jacob, D. J., Kurosu, T. P., Spurr, R. J. D., Bucsela, E., Gleason, J.F., Palmer, P. I., Bey, I., Fiore, A. M., Li, Q., Yantosca, R. M., and Koelemeijer, R. B. A.: An improved retrieval of tropospheric nitrogen dioxide from GOME, J. Geophys. Res., 107(D20), 4437, doi:10.1029/2001JD001027, 2002.

Mayer, B. and Kylling, A.: Technical note: The libRadtran software package for radiative transfer calculations - description and examples of use, Atmos. Chem. Phys., 5, 1855-1877, doi:10.5194/acp-5-1855-2005, 2005.

McConnel, J. C., Henderson, G. S., Barrie, L., Bottenheim, J., Niki, H., Langford, C. H., and Templeton, E. M. J.: Photochemical bromine production implicated in Arctic boundary-layer ozone depletion, Nature, 355, 150-152, 1992.

McElroy, M. B., Salawitch, R. J., Wofsy, S. C., and Logan, J. A.: Reductions of Antarctic ozone due to synergetic interactions of chlorine and bromine, Nature, 321, 759-762, 1986.

Meller, R. and Moortgat, G. K.: Temperature dependence of the absorption cross-section of HCHO between 223 and $323 \mathrm{~K}$ in the wavelength range $225-375 \mathrm{~nm}$, J. Geophys. Res., 105(D6), 7089-7102, doi:10.1029/1999JD901074, 2000.

Montzka, S. A., Butler, J. H., Hall, B. D., Mondeel, D. J., and Elkins, J. W.: A decline in tropospheric organic bromine, Geophys. Res. Lett., 30(15), 1826, doi:10.1029/2003GL017745, 2003.

Munro, R., Eisinger, M., Anderson, C., Callies, J., Corpaccioli, E., Lang, R., Lefebvre, A., Livschitz, Y., and Albinana, A. P.: GOME-2 on MetOp, in: Proc. of The 2006 EUMETSAT Meteorological Satellite Conference, Helsinki, Finland, 12-16 June 2006, EUMETSAT, p. 48, 2006.

Neuman, J. A., Nowak, J. B., Huey, L. G., Burkholder, J. B., Dibb, J. E., Holloway, J. S., Liao, J., Peischl, J., Roberts, J. M., Ryerson, T. B., Scheuer, E., Stark, H., Stickel, R. E., Tanner, D. J., and Weinheimer, A.: Bromine measurements in ozone depleted air over the Arctic Ocean, Atmos. Chem. Phys., 10, 6503-6514, doi:10.5194/acp-10-6503-2010, 2010.

Oppenheimer, C., Tsanev, V. I., Braban, C. F, Cox, R. A., Adams, J. W., Aiuppa, A., Bobrowski, N., Delmelle, P., Barclay, J., and McGonigle, A. J.: BrO formation in volcanic plumes, Geochim. Cosmochim. Acta, 70, 2935-2941, 2006.

Palmer, P. I., Jacob, D. J., Chance, K., Martin, R. V., Spurr,
R. J. D., Kurosu, T. P., Bey, I., Yantosca, R., Fiore, A., and $\mathrm{Li}, \mathrm{Q}$.: Air-mass factor formulation for spectroscopic measurements from satellites: application to formaldehyde retrievals from GOME, J. Geophys. Res., 106(D13), 14539-14550, doi:10.1029/2000JD900772, 2001.

Platt, U. and Stutz, J.: Differential Optical Absorption Spectroscopy (DOAS), Principle and Applications, ISBN 3-34021193-4, Springer Verlag, Heidelberg, Germany, 2008.

Read, K. A., Mahajan, A. S., Carpenter, L. J., Evans, M. J., Faria, B. V. E., Heard, D. E., Hopkins, J. R., Lee, J. D., Moller, S. J., Lewis, A. C., Mendes, L., McQuaid, J. B., Oetjen, H., SaizLopez, A., Pilling, M. J., and Plane, J. M. C.: Extensive halogenmediated ozone destruction over the tropical Atlantic Ocean, Nature, 453, 1232-1235, 2008.

Richter, A.: Absorptionspektroskopische Messungen stratosphärischer Spurengase über Bremen, $55^{\circ} \mathrm{N}, \mathrm{PhD}$ thesis, Inst. für Umweltphysik, Univ. of Bremen, Bremen, Germany, 1997.

Richter, A., Wittrock, F., Eisinger, M., and Burrows, J. P.: GOME Observations of Tropospheric BrO in Northern Hemispheric Spring and Summer 1997, Geophys. Res. Lett., 25, 2683-2686, 1998.

Richter, A., Wittrock, F., Ladstätter-Weissenmayer, A., and Burrows, J. P.: GOME measurements of stratospheric and tropospheric BrO, Adv. Space Res., 29, 1667-1672, 2002.

Richter, A., Burrows, J. P., Nüß, H., Granier, C, and Niemeier, U.: Increase in tropospheric nitrogen dioxide over China observed from space, Nature, 437, 129-132, doi:10.1038/nature04092, 2005.

Rodgers, C. D.: Inverse Methods for Atmospheric Sounding, Theory and Practice, World Scientific Publishing, Singapore, NewJersey, London, Hong Kong, 2000.

Rozanov, A., Rozanov, V., and Burrows, J. P.: A numerical radiative transfer model for a spherical planetary atmosphere: Combined differential integral approach involving the Piccard iterative approximation, J. Quant. Spectrosc. Radiat. Transfer, 69, 491-512, 2001.

Saiz-Lopez, A., Plane, J. M. C., and Shilito, J. A.: Bromine oxide in the mid-latitude marine boundary layer, Geophys. Res. Lett., 31, L03111, doi:10.1029/2003GL018956, 2004.

Salawitch, R. J., Canty, T., Kurosu, T., Chance, K., Liang, Q., da Silva, A., Pawson, S., Nielsen, J. E., Rodriguez, J. M., Bhartia, P. K., Liu, X., Huey, L. G., Liao, J., Stickel, R. E., Tanner, D. J., Dibb, J. E., Simpson, W. R., Donohoue, D., Weinheimer, A., Flocke, F., Knapp, D., Montzka, D., Neuman, J. A., Nowak, J. B., Ryerson, T. B., Oltmans, S., Blake, D. R., Atlas, E. L., Kinnison, D. E., Tilmes, S., Pan, L. L., Hendrick, F., Van Roozendael, M., Kreher, K., Johnston, P. V., Gao, R. S., Johnson, B., Bui, T. P., Chen, G., Pierce, R. B., Crawford, J. H., and Jacob, D. J: A new interpretation of total column BrO during Arctic Spring, Geophys. Res. Lett. (Frontier Articles), 37, L21805, doi:10.1029/2010GL043798, 2010.

Schoeberl, M. R.: Extratropical stratosphere-troposphere mass exchange, J. Geophys. Res., 109, D13303, doi:10.1029/2004JD004525, 2004.

Schofield, R., Kreher, K., Connor, B. J., Johnston, P. V., Thomas, A., Shooter, D., Chipperfield, M. P., Rodgers, C. D., and Mount, G. H.: Retrieved tropospheric and stratospheric $\mathrm{BrO}$ columns over Lauder, New Zealand., J. Geophys. Res., 109, D14304, 
doi:10.1029/2003JD004463, 2004.

Schofield, R., Johnston, P. V., Thomas, A., Kreher, K., Connor, B. J., Wood, S., Shooter, D., Chipperfield, M. P., Richter, A., von Glasow, R., and Rodgers, C. D.: Tropospheric and stratospheric BrO columns over Arrival Heights, Antartica, 2002, J. Geophys. Res., 111, D22310, doi:10.1029/2005JD007022, 2006.

Schroeder, W. H., Anlauf, K. G., Barrie, L. A., Lu, J. Y., Steffen, A., Scheenberger, D. R., and Berg, T.: Arctic springtime depletion of mercury, Nature, 394, 331-332, 1998.

Siddans, R., Latter, B. G., Kerridge, B. J., Smeets, J., Otter, G., and Slijkhuis, S.: Analysis of GOME-2, Slit function Measurements Final Report, Eumetsat Contract No. EUM/CO/04/1298/RM, 2006.

Simpson, W. R., von Glasow, R., Riedel, K., Anderson, P., Ariya, P., Bottenheim, J., Burrows, J., Carpenter, L. J., Frieß, U., Goodsite, M. E., Heard, D., Hutterli, M., Jacobi, H.-W., Kaleschke, L., Neff, B., Plane, J., Platt, U., Richter, A., Roscoe, H., Sander, R., Shepson, P., Sodeau, J., Steffen, A., Wagner, T., and Wolff, E.: Halogens and their role in polar boundary-layer ozone depletion, Atmos. Chem. Phys., 7, 4375-4418, doi:10.5194/acp-74375-2007, 2007.

Sinnhuber, B.-M., Rozanov, A., Sheode, N., Afe, O. T., Richter, A., Sinnhuber, M., Wittrock, F., Stiller, G. P., von Clarmann, T., Linden, A., and Burrows, J. P.: Global observations of stratospheric bromine monoxide from SCIAMACHY, Geophys. Res. Lett., 32, L20810, doi:10.1029/2005GL023839, 2005.

Sirois, A. and Barrie, L.: Arctic lower tropospheric aerosol trends and composition at Alert, Canada: 1980-1995, J. Geophys. Res., 104(D9), 11599-11618, 1999.

Theys, N., Van Roozendael, M., Hendrick, F., Fayt, C., Hermans, C., Baray, J.-L., Goutail, F., Pommereau, J.-P., and De Mazire, M.: Retrieval of stratospheric and tropospheric $\mathrm{BrO}$ columns from multi-axis DOAS measurements at Reunion Island $\left(21^{\circ} \mathrm{S}\right.$, $56^{\circ}$ E), Atmos. Chem. Phys., 7, 4733-4749, doi:10.5194/acp-74733-2007, 2007.

Theys, N., Van Roozendael, M., Dils, B., Hendrick, F., Hao, N., and De Mazière, M.: First satellite detection of volcanic bromine monoxide emission after the Kasatochi eruption, Geophys. Res. Lett., 36, L03809, doi:10.1029/2008GL036552, 2009a.

Theys, N., Van Roozendael, M., Errera, Q., Hendrick, F., Daerden, F., Chabrillat, S., Dorf, M., Pfeilsticker, K., Rozanov, A., Lotz, W., Burrows, J. P., Lambert, J.-C., Goutail, F., Roscoe, H. K., and De Mazière, M.: A global stratospheric bromine monoxide climatology based on the BASCOE chemical transport model, Atmos. Chem. Phys., 9, 831-848, 2009b, http://www.atmos-chem-phys.net/9/831/2009/.

Van Roozendael, M., Wagner, T., Richter, A., Pundt, I., Arlander, D., Burrows, J. P., Chipperfield, M., Fayt, C., Johnston, P. V., Lambert, J.-C., Kreher, K., Pfeilsticker, K., Platt, U., Pommereau, J.-P., Sinnhuber, B.-M., Tornkvist, K. K., and Wittrock, F.: Intercomparison of $\mathrm{BrO}$ measurements from ERS-2 GOME, ground-based and balloon platforms , Adv. Space Res., 29, 16611666, 2002.

Van Roozendael, M., De Smedt, I., Fayt, C., Wittrock, F., Richter, A., Afe, O.: First validation of SCIAMACHY BrO columns, in Proc. Second Workshop on the Atmospheric Chemistry Validation of ENVISAT (ACVE-2), Frascati, Italy, 3-7 May, 2004.
Viscardy, S., Errera, Q., Christophe, Y., Chabrillat, S., and Lambert, J.-C.: Evaluation of ozone analysis from UARS MLS assimilation by BASCOE between 1992 and 1997, JSTARS 3, 190-202, 2010.

Vogt, R., Crutzen, P. J., and Sander, P.: A mechanism for halogen release from sea-salt aerosol in the remote marine boundary layer, Nature, 383, 327-330, 1996.

von Glasow, R. and Crutzen, P. J.: Tropospheric Halogen Chemistry, Vol. 4.02, in: Treatise on Geochemistry Update 1, edited by: Holland, H. D. and Turekian, K. K., Elsevier-Pergamon, Oxford, UK, 1-67, 2007.

von Glasow, R., von Kuhlmann, R., Lawrence, M. G., Platt, U., and Crutzen, P. J.: Impact of reactive bromine chemistry in the troposphere, Atmos. Chem. Phys., 4, 2481-2497, doi:10.5194/acp4-2481-2004, 2004.

Vountas, M., Rozanov, V. V., and Burrows, J. P.: Ring effect: Impact of rotational raman scattering on radiative transfer in earth's atmosphere, J. Quant. Spectrosc. Radiat. Transfer., 60, 943-961, 1998.

Wagner, T. and Platt, U.: Satellite mapping of enhanced BrO concentrations in the troposphere, Nature, 395, 486-490, 1998.

Wagner, T., Leue, C., Wenig, M., Pfeilsticker, K., and Platt, U.: Spatial and temporal distribution of enhanced boundary layer $\mathrm{BrO}$ concentrations measured by the GOME instrument aboard ERS2, J. Geophys. Res., 106, 24225-24236, 2001.

Wang, P., Stammes, P., van der A, R., Pinardi, G., and van Roozendael, M.: FRESCO+: an improved $\mathrm{O}_{2}$ A-band cloud retrieval algorithm for tropospheric trace gas retrievals, Atmos. Chem. Phys., 8, 6565-6576, doi:10.5194/acp-8-6565-2008, 2008.

Wennberg, P.: Atmospheric chemistry: Bromine explosion, Nature, 397, 299-301, 1999.

World Meteorological Organization (WMO): Scientific Assessment of Ozone Depletion: 2006, Global ozone research and monitoring project, Chapter 2: Halogenated Very Short-Lived Substances, Rep. 50, Geneva, Switzerland, 2007.

Yang, X., Cox, R. A., Warwick, N. J., Pyle, J. A., Carver, G. D., O'Connor, F. M., and Savage, N. H.: Tropospheric bromine chemistry and its impacts on ozone: A model study, J. Geophys. Res., 110, D23311, doi:10.1029/2005JD006244, 2005.

Yang, X., Pyle, J. A., and Cox, R. A.: Sea salt aerosol production and bromine release: Role of snow on sea ice, Geophys. Res. Lett., 35, L16815, doi:10.1029/2008GL034536, 2008.

Yang, X., Pyle, J. A., Cox, R. A., Theys, N., and Van Roozendael, M.: Snow-sourced bromine and its implications for polar tropospheric ozone, Atmos. Chem. Phys., 10, 7763-7773, doi:10.5194/acp-10-7763-2010, 2010.

Ziemke, J. R., Chandra, S., and Bhartia, P. K.: "Cloud slicing": A new technique to derive upper tropospheric ozone from satellite measurements, J. Geophys. Res., 106(D9), 9853-9867, 2001. 